\title{
Controlling pore-scale processes to tame subsurface biomineralization
}

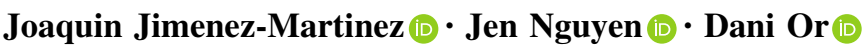

Received: 28 August 2021/Accepted: 6 December 2021/Published online: 21 January 2022

(C) The Author(s) 2022

\begin{abstract}
Microorganisms capable of biomineralization can catalyze mineral precipitation by modifying local physical and chemical conditions. In porous media, such as soil and rock, these microorganisms live and function in highly heterogeneous physical, chemical and ecological microenvironments, with strong local gradients created by both microbial activity and the pore-scale structure of the subsurface. Here, we focus on extracellular bacterial biomineralization, which is sensitive to external heterogeneity,
\end{abstract}

Joaquin Jimenez-Martinez and Jen Nguyen contributed equally.

J. Jimenez-Martinez ( $\square)$

Department of Water Resources and Drinking Water,

Eawag, Dübendorf, Switzerland

e-mail: joaquin.jimenez@eawag.ch; jjimenez@ethz.ch

J. Jimenez-Martinez

Department of Civil, Environmental and Geomatic

Engineering, ETH Zurich, Zürich, Switzerland

J. Nguyen $(\bowtie)$

Department of Microbiology and Immunology, University of British Columbia, Vancouver, BC V6T 1Z3, Canada

e-mail: j.kimthu.nguyen@gmail.com

J. Nguyen

School of Biomedical Engineering, University of British

Columbia, Vancouver, BC V6T 1Z3, Canada

D. Or

Division of Hydrologic Sciences, Desert Research

Institute, Reno, NV, USA and review the pore-scale processes controlling microbial biomineralization in natural and engineered porous media. We discuss how individual physical, chemical and ecological factors integrate to affect the spatial and temporal control of biomineralization, and how each of these factors contributes to a quantitative understanding of biomineralization in porous media. We find that an improved understanding of microbial behavior in heterogeneous microenvironments would promote understanding of natural systems and output in diverse technological applications, including improved representation and control of fluid mixing from pore to field scales. We suggest a range of directions by which future work can build from existing tools to advance each of these areas to improve understanding and predictability of biomineralization science and technology.

Keywords Biomineralization · Porous media - Porescale $\cdot$ Microenvironments $\cdot$ Fluid mixing

\section{Introduction}

Biomineralization is a widespread process by which organisms produce minerals as part of their metabolism. Here, we focus on extracellular biomineralization, also called biologically induced-mineralization, and its role in shaping biophysical processes in natural 
and engineered porous media (e.g., soils, aquifers, concrete). The most studied extracellularly formed minerals are silicates, carbonates and metal oxides. Some macroorganisms, such as mollusks, are capable of extracellular biomineralization (Skinner and Jahren, 2005), though the majority is performed by microbes (van Cappellen 2003; Philipps et al., 2013; Dhami et al. 2013; Zhu and Dittrich 2016; Anbu et al. 2016; Gahlawat and Choundhury, 2019). In fact, bacterial biomineralization may have produced the Earth's oldest macroscopic fossils. Nearly all modern conical stromatolites display a characteristic spacing between cones, consistent with spacing found in ancestral stromatolites formed 2.8 billion years ago (Petroff et al. 2010). This remarkably consistent spacing has been attributed to the periodic rhythms of mineral precipitation, driven by the daily metabolic cycles of photosynthetic cyanobacteria (Petroff et al. 2010). Thus, the spatial organization of biomineralization is dependent on microbial responses to dynamic environmental conditions. In this review, we focus on the dynamics of extracellular biomineralization, which we now refer to simply as "biomineralization", by bacteria in a markedly heterogeneous and spatially structured environment: porous media.

A mechanistic understanding of biomineralization dynamics is not only important for interpreting Earth's chemical and geological records (Pérez-Huerta et al. 2018), but also for the success of several environmental and industrial applications. Considered an environmentally friendly process, biomineralization has been applied towards the removal of harmful metals and radionuclides from soil (Gavrilescu et al. 2009; Spycher et al. 2011; Li et al. 2016), the extraction of valuable metals from rock and mine waste (i.e., biomining) (Johnson 2014), the removal of ions and hydrocarbons from wastewater and polluted sites (Atekwana and Aal 2015), geological sequestration of $\mathrm{CO}_{2}$ (Cunningham et al. 2009; Phillips et al. 2012), enhanced oil recovery (Zhu et al. 2013), and the remediation of building materials such as ornamental stones and concrete (Jiménez-López et al. 2007; De Muynck et al. 2010). A growing number of geomechanical applications have used biomineralization to consolidate and stabilize soil and rock (Mitchell and Santamarina 2005; Ivanov and Chu. 2008; Chou et al. 2011; DeJong et al. 2013; Salifu et al. 2016; Mujah et al. 2017) and to mitigate seismic-induced soil liquefaction (Burbank et al. 2011; Han et al. 2016;
Xiao et al. 2018; Zango et al. 2018). Biomineralization has also been considered for large-scale environmental applications such as the sealing of geologic formations produced by fracking (Phillips et al. 2013).

The promise of understanding and harnessing biomineralization at geologically and technologically relevant scales (i.e., mesoscale, meters and kilometers) has motivated interest in the spatial distribution of biomineralization, which is controlled by pore-scale processes. Biomineralization occurs within the pores or cracks of porous or fractured media, which are matrixes of solid grains and void spaces (i.e., the pores or cracks). The structure of these void spaces varies considerably, and their volumes can be occupied by diverse physical and chemical microenvironments. Whether these voids contain a single or multiple fluid and/or gas phases determines whether biomineralization occurs under saturated (i.e., no continuous gas phase) or partially saturated conditions. These differences in hydration state and phase distribution within the porous media dictate an array of other constraints on gas transport and biological function (Tecon and Or 2017). The high degree of heterogeneity in porous media challenges ability to spatially control the extent, rate and uniformity of biomineralization for desired outcomes.

The specific objectives of this review are: (i) to disentangle the numerous factors (e.g., fluid flow dynamics, environmental chemistry and microbial ecology) that contribute to microenvironment heterogeneity and currently complicate the predictability of bacterial biomineralization, and (ii) to outline experimental and computational strategies for integrating existing tools and new approaches towards improving spatial control over biomineralization in porous media (Fig. 1). We focus primarily on microbially-induced carbonate precipitation in porous subsurface environments as a model system. However, many other systems are porous (e.g., bones, filters, concrete, cultural heritage monuments) and would benefit from the concepts and insights outlined here.

\section{Key ingredients for biomineralization in porous and fractured media}

The mechanisms that promote or suppress biomineralization in porous media are intimately linked to physical and chemical heterogeneity, fluid flow 


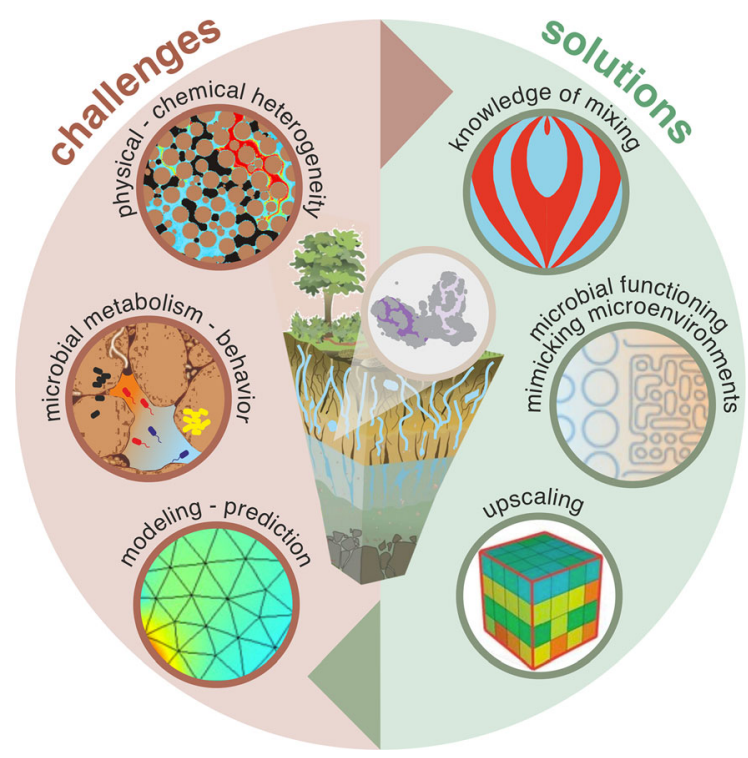

Fig. 1 Biomineralization in natural (e.g., soils and aquifers) and engineered (e.g., building materials) porous systems is controlled by multiple interacting components: fluid flow dynamics, environmental chemistry, microbial activity and mineralogy of the solid substrate. The intrinsic heterogeneity of porous media affects all these processes, rendering the prediction and control of extracellular biomineralization processes highly uncertain. We propose several potential solutions requiring further research on the understanding of mixing in the porous media and microbial behavior in heterogeneous microenvironments, and the inclusion of pore-scale process in large scale modeling approaches (upscaling)

dynamics and microbial ecology. Here, we focus on pore-scale processes that affect the immediate environment surrounding bacterial cells and discuss how each of these factors contribute to pore-to-pore variability in biomineralization rates, producing challenges for reliable predictions or engineered applications of biomineralization at meso- or field-scale.

\subsection{Microbial metabolism}

From soils to sediments, aquifers to hot springs, and lakes to oceans, microorganisms produce a large variety of biominerals, including phosphates, silicates, carbonates and oxides, and sulfates and sulfides of various metals (Sarikaya 1999; Riding and Awramik 2000). Biominerals may differ distinctly from their inorganically formed equivalents in shape (Mann 2000), size, crystallinity, isotopic, and trace element composition (Heim 2011). Evidence suggests that biomineralizing microorganisms are ubiquitous in all geologic environments (i.e., soils and rocks) and that their activity plays important roles in the functions of local and global ecosystems (Brussaard 1997). Biominerals are key components of global biogeochemical cycles and serve as critical indicators of past environmental conditions when observed in geological and fossil records (Weiner and Dove 2003).

Microbially-induced carbonate precipitation (MICP) is one of the most studied process of bacterial biomineralization in porous media and the most abundant globally, accounting for up to $42 \%$ of the total carbon on Earth (Ehrlich 1998). Carbonate formed through MICP fixes atmospheric $\mathrm{CO}_{2}$ and is thus a major sink of this greenhouse gas (Prentice et al. 2001). Microorganisms can catalyze the precipitation of carbonate via different metabolic pathways, including urea hydrolysis, denitrification, ammonification, sulfate reduction, methane oxidation and photosynthesis (see Eq. 1-6) (Achal et al. 2015).

$$
\begin{aligned}
& \text { Urea hydrolysis: } \quad \mathrm{CO}\left(\mathrm{NH}_{2}\right)_{2}+\mathrm{H}_{2} \mathrm{O} \underset{\text { urease }}{\longrightarrow} 2 \mathrm{NH}_{3}+\mathrm{CO}_{2} \\
& \mathrm{NH}_{3}+\mathrm{H}_{2} \mathrm{O} \leftrightarrow \mathrm{NH}_{4}^{+}+\mathrm{OH}^{-} \\
& \mathrm{CO}_{2}+\mathrm{OH}^{-} \leftrightarrow \mathrm{HCO}_{3}^{-} \\
& \mathrm{Ca}^{2+}+\mathrm{HCO}_{3}^{-}+\mathrm{OH}^{-} \leftrightarrow \mathrm{H}_{2} \mathrm{O}+\mathrm{CaCO}_{3}
\end{aligned}
$$

Denitrification: $\quad 1.25 \mathrm{CH}_{2} \mathrm{O}+\mathrm{NO}_{3}^{-} \rightarrow 1.25 \mathrm{CO}_{2}$

$$
\begin{array}{r}
+0.5 \mathrm{~N}_{2}+0.75 \mathrm{H}_{2} \mathrm{O}+\mathrm{OH}^{-} \\
\mathrm{Ca}^{2+}+\mathrm{CO}_{2}(\mathrm{aq})+2 \mathrm{OH}^{-} \rightarrow \mathrm{CaCO}_{3}+\mathrm{H}_{2} \mathrm{O}
\end{array}
$$

Amonification: Amino acids $+\mathrm{O}_{2}+\mathrm{Ca}^{2+}$

$$
\rightarrow \mathrm{NH}_{4}^{+}+\mathrm{CaCO}_{3}+\mathrm{H}^{+}
$$

Sulfate reduction: $6 \mathrm{CaSO}_{4}+4 \mathrm{H}_{2} \mathrm{O}+6 \mathrm{CO}_{2}$

$$
\rightarrow 6 \mathrm{CaCO}_{3}+4 \mathrm{H}_{2} \mathrm{~S}+2 \mathrm{~S}+11 \mathrm{O}_{2}
$$

Methane oxidation: $\mathrm{CH}_{4}+\mathrm{SO}_{4}^{2-} \mathrm{Ca}^{2+}$

$$
\rightarrow \mathrm{H}_{2} \mathrm{O}+\mathrm{CaCO}_{3}+\mathrm{H}_{2} \mathrm{~S}
$$

Photosynthesis: $2 \mathrm{HCO}_{3}^{-}+\mathrm{Ca}^{2+}$

$$
\rightarrow \mathrm{CH}_{2} \mathrm{O}+\mathrm{CaCO}_{3}+\mathrm{O}_{2}
$$

MICP is performed by diverse microorganisms (bacteria, fungi, algae and metazoans) (Gadd 2010) and contributes to major geological processes, including carbonate sediment formation and lithification and dolomite precipitation (Sánchez-Román et al. 2011; 
Zhang 2020). This review focuses on bacterial carbonate biomineralization in porous media, though many microorganisms, including fungi and algae (Table 1), catalyze reactions and produce precipitates important to the chemistry and structure of their environments.

The rates of bacterial biomineralization are orders of magnitude higher than that of mineral precipitation under abiotic conditions (Zhu and Dittrich 2016; Prasianakis et al. 2017). Typical abiotic rates of $\mathrm{CaCO}_{3}$ (calcite) precipitation range from $11^{-10}$ to $6.510^{-9} \mathrm{~g} \mathrm{~cm}^{-2} \mathrm{~s}^{-1}$ for spring-fed streams and from $10^{-20}$ to $10^{-8} \mathrm{~g} \mathrm{~cm}^{-2} \mathrm{~s}^{-1}$ for deep sea sediments (Sanjuan and Girard 1996). In contrast, rates of carbonate production by urea hydrolysis range from $3.510^{-6}$ to $1.410^{-5} \mathrm{~g} \mathrm{~cm}^{-2} \mathrm{~s}^{-1}$ with Bacillus species (Chu et al. 2012) and from $9.310^{-9}$ to $5.110^{-8}$ $\mathrm{g} \mathrm{cm}^{-2} \mathrm{~s}^{-1}$ with Sporosarcina pasteurii (Cuthbert et al. 2012). Single-cell biomineralization rates have been estimated to be $7.210^{-13}$ and $1610^{-13} \mathrm{~g} \mathrm{Ca}^{2+}$ $\mathrm{h}^{-1}$ cell $^{-1}$ with $S$. pasteurii and Bacillus pasteurii, respectively (Ganendra et al. 2014).

The rate enhancement achieved by biotic mineralization is facilitated by individual cells and bacterial biofilms, which are aggregates of cells residing within a self-produced extracellular matrix (Conolly et al., 2015; Keren-Paz et al. 2018). Both can catalyze biomineralization by two primary processes. In the first, mineral precipitation is a by-product of bacterial metabolism. For example, bacterial hydrolysis of urea (via urea amidohydrolase) produces bicarbonate and ammonium, increasing environmental $\mathrm{pH}$ and therefore calcite precipitation when enough dissolved calcium ions are present (Eq. 1). In the second, bacteria can nucleate mineral precipitation on their cell walls or on the extracellular matrix of biofilms (i.e., extracellular polymeric substances, EPS), which provide a scaffold for biomineralization (Zhu and Dittrich 2016; Flemming et al. 2016; Bao et al. 2018; Han et al. 2019). Increased EPS in the environment increases the consumption of calcium from solution by increasing the number nucleation sites (Bains et al. 2015). Because the exact sites of nucleation are dependent on the charge of cell wall or EPS functional groups (Görgen et al., 2021) (Fig. 2a), the precise biochemical composition of EPS (which varies between bacterial taxa) influences the resulting morphology of mineralized carbonate (Braissant et al. 2003; Ercole et al. 2007). Mineralized carbonate generally precipitates on cell surfaces layer by layer (i.e., successive stratification), implying that bacteria can eventually embed themselves in precipitate (De Muynck et al. 2010; Ghosh et al., 2019) (Fig. 2b). Whether the products of biomineralization are of ecological benefit to these bacteria remains unclear (Dhami et al. 2013). Some authors argue that the organisms construct a precipitated environment to their advantage (Ehrlich 1996; McConnaughey and Whelan 1997), whereas others find the precipitation an incidental by-product of metabolism (Knorre and Krumbein 2000).

In either case, bacteria alter the rates of mineral precipitation by altering the local environment. That the rate of biomineralization reactions is strongly dependent on environmental conditions complicates our ability to accurately predict biomineralization rates in environments like porous media, where microscale spatial heterogeneity in many variables is inherent.

\subsection{The physico-chemical environment}

The porous environment in which bacteria reside (i.e., the host matrix) creates strong gradients in a number of physico-chemical variables, including temperature, salinity, $\mathrm{pH}$, redox conditions, and substrate composition (Hammes and Verstraete 2002; Mortensen et al. 2011; Han et al. 2019). These variables each modulate all biomineralization processes, from the precipitation of minerals (Liang et al. 2015; Zhu and Dittrich 2016; Bindschedler et al. 2016) to the weathering of parent rock minerals (Gorbushina 2007; Parchert et al. 2012; Seiffert et al. 2014).

Increases in temperature generally increase the rate of MICP (Ferris et al. 2004; Mitchell and Ferris, 2005; Tobler et al. 2011). For example, an increase in ambient temperature from 10 to $20{ }^{\circ} \mathrm{C}$ increased $B$. pasteurii calcite precipitation by $6 \%$ (from $1.9610^{-10}$ to $2.110^{-10} \mathrm{~g} \mathrm{~cm}^{-3} \mathrm{~s}^{-1}$ ), even at low concentrations of urea substrate (Mitchell and Ferris, 2005). Even higher temperatures within the mesophilic range (20-45 ${ }^{\circ} \mathrm{C}$ ) enhance microbial activity, mineral nucleation and growth (Nemati and Voordouw 2003). When incubated on agar plates, Bacillus sphaericus was observed to produce carbonate at $13 \%$ higher rates at $37{ }^{\circ} \mathrm{C}$ than $10{ }^{\circ} \mathrm{C}$ (De Muynck et al. 2013).

These relations between biomineralization characteristics and temperature serve only as general 
Table 1 Metabolic pathways of carbonate precipitation in diverse microorganisms

\begin{tabular}{|c|c|c|}
\hline $\begin{array}{l}\text { Metabolic } \\
\text { pathway }\end{array}$ & Species & References \\
\hline \multirow[t]{13}{*}{ Urea hydrolysis } & Bacteria & \\
\hline & $\begin{array}{l}\text { Sporosarcina } \\
\text { pasteurii }\end{array}$ & $\begin{array}{l}\text { Cunningham et al. (2009); Chou et al. (2011); Cuthbert et al. (2012); Ghosh et al. (2019); } \\
\text { Mortensen et al. (2011); Martin et al. (2012); Terzis \& Laloui (2018); Dawaoud et al. } \\
\text { (2014a,b); Zhao et al. (2014); Schultz et al. (2011); Al Qabany et al. (2012); Zambare } \\
\text { et al. (2012); Lauchnor et al. (2013); Hommel et al. (2016); DeJong et al. (2014); Gomez } \\
\text { et al. (2016); Nassar et al. (2018); Barkouki et al. (2011); Martinez et al. (2014); Ebigbo } \\
\text { et al. (2012); Wang et al. (2019); Fridjonsson et al. (2011); Lauchnor et al. (2015); } \\
\text { Whiffin et al. (2007) }\end{array}$ \\
\hline & Bacillus cohnii & Zhang et al. (2017) \\
\hline & Bacillus subtilis & Sarkar et al. (2015) \\
\hline & Escherichia coli & Connolly et al. $(2013,2015)$ \\
\hline & $\begin{array}{l}\text { Pseudomonas } \\
\text { aeruginosa }\end{array}$ & Connolly et al. (2013); Bai et al. (2017) \\
\hline & Bacillus sphaericus & De Muynck et al. (2011, 2013); Cheng et al. (2013); Wang et al. 2012b) \\
\hline & $\begin{array}{l}\text { Sporosarcina } \\
\text { psychrophila }\end{array}$ & De Muynck et al. (2013) \\
\hline & $\begin{array}{r}\text { Terrabacter } \\
\text { tumescens }\end{array}$ & Li et al. (2016) \\
\hline & Bacillus megaterium & Lian et al (2006) \\
\hline & Algae & \\
\hline & Mychonastes sp. & Ariyanti \& Handayani (2012) \\
\hline & Chlorella sp. & Ariyanti \& Handayani (2012) \\
\hline \multirow[t]{3}{*}{ Ammonification } & Bacteria & \\
\hline & Myxococcus xanthus & Jiménez-López et al. (2007); Rodriguez-Navarro et al. (2012); Chekroun et al. (2004) \\
\hline & $\begin{array}{l}\text { Brevundimonas } \\
\text { diminuta }\end{array}$ & Rodriguez-Navarro et al. (2012) \\
\hline \multirow[t]{6}{*}{ Denitrification } & Bacteria & \\
\hline & $\begin{array}{l}\text { Halomonas } \\
\quad \text { halodenitrificans }\end{array}$ & Martin et al. (2013) \\
\hline & $\begin{array}{c}\text { Pseudomonas } \\
\text { aeruginosa }\end{array}$ & Erşan et al. (2015) \\
\hline & $\begin{array}{c}\text { Diaphorobacter } \\
\text { nitroreducens }\end{array}$ & Erşan et al. (2015) \\
\hline & $\begin{array}{l}\text { Pseudomonas } \\
\text { stutzeri }\end{array}$ & Singh et al. (2015) \\
\hline & Bacteria & \\
\hline \multirow{2}{*}{$\begin{array}{l}\text { Sulfate } \\
\text { reduction }\end{array}$} & Desulfovibrio & Atlas and Rude (1998) \\
\hline & Bacteria & \\
\hline \multirow{2}{*}{$\begin{array}{l}\text { Methane } \\
\text { oxidation }\end{array}$} & Methanosarcinales & Nauhaus et al. (2002) \\
\hline & Desulfococcus & \\
\hline \multirow[t]{3}{*}{ Photosynthesis } & Cyanobacteria & \\
\hline & Synechococcus & Southam (2000) \\
\hline & Nostoc punctiforme & Seiffert et al. (2014) \\
\hline $\begin{array}{l}\text { Unspecified } \\
\text { pathway }\end{array}$ & Bacteria & \\
\hline
\end{tabular}


Table 1 continued

\begin{tabular}{lll}
\hline $\begin{array}{l}\text { Metabolic } \\
\text { pathway }\end{array}$ & Species & References \\
\hline & $\begin{array}{l}\text { Arthrobacter } \\
\text { sulfonivorans }\end{array}$ & Keiner et al. (2015) \\
& Fungi & \\
Aspergillus nidulans & Menon et al. (2019) \\
& Knufia petricola & Seiffert et al. (2014) \\
\hline
\end{tabular}

A
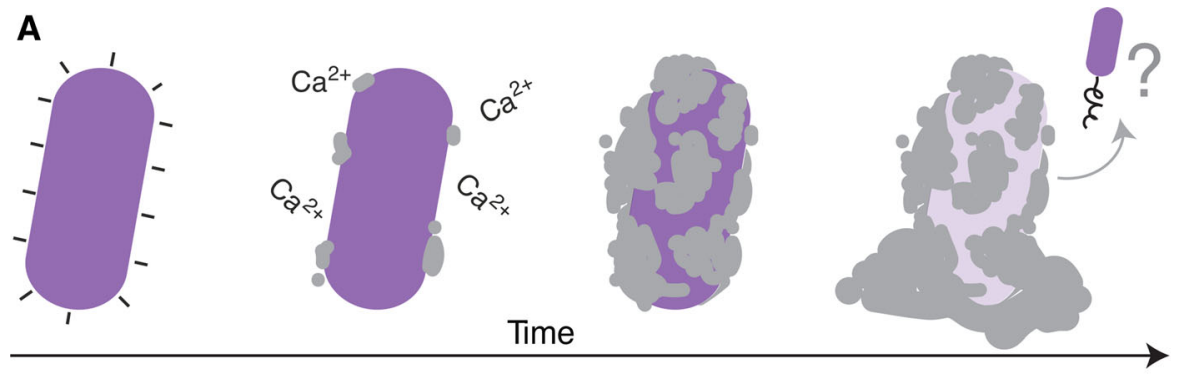

B

C

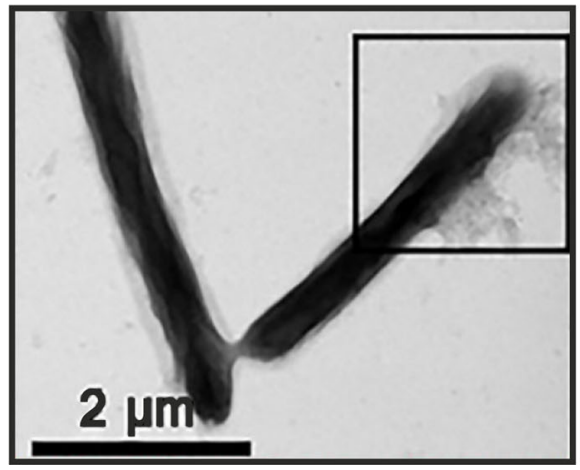

Fig. 2 Microbially-induced mineral precipitation. a Precipitate, although distributed heterogeneously at the cell wall, encapsulates the bacterium over time. $\mathrm{Ca}^{2+}$ ions in the solution are attracted to the bacterial cell wall due its negative charge. The presence of $\mathrm{Ca}^{2+}$ ions can result in local supersaturation and precipitation of calcium carbonate on the bacterial cell wall.

guidelines. Very high temperatures $\left(>50{ }^{\circ} \mathrm{C}\right)$ can kill ureolytic microorganisms (Rebata-Landa 2007) and decrease the size of carbonate crystals, from 15 to $20 \mu \mathrm{m}$ at $25^{\circ} \mathrm{C}$ to $2-5 \mu \mathrm{m}$ at $50{ }^{\circ} \mathrm{C}$ (Cheng et al. 2014). Certain organisms, such as Sporosarcina psychrophila, do not produce significant amounts of calcium carbonate under mesophilic conditions (Tobler et al. 2011). Additionally, the urease enzyme can function extracellularly (Dupraz et al. 2009b) even at temperatures higher than the mesophilic range

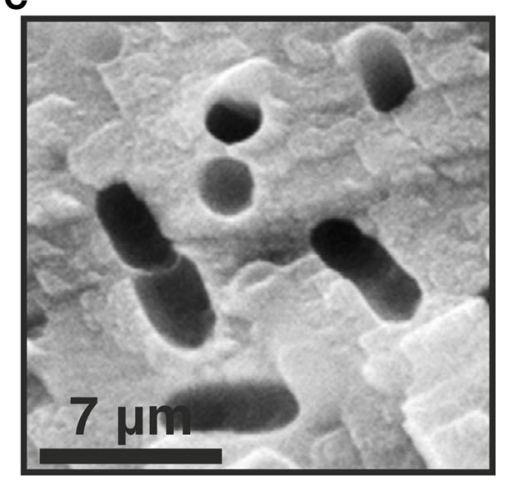

Imprints of bacteria appear in these minerals, either due to cell death or cell migration after substantial precipitation. b Electron microscopy image of $S$. pasteurii cells. The inset square indicates the formation of $\mathrm{CaCO}_{3}$ coating the cell surface ( adapted from Ghosh et al. 2019) c Bacterial "voids" within the calcium carbonate (adapted from De Muynck et al., 2010)

(Bachmeier et al. 2002). Calcite produced from purified urease has been observed to increase by $100 \%$ between 22 and $50{ }^{\circ} \mathrm{C}$, from $2.510^{-8}$ to 5 $10^{-8} \mathrm{~g} \mathrm{~cm}^{-3} \mathrm{~s}^{-1}$ (Nemati and Voordouw, 2003). In short, while biomineralization depends on temperature, the precise nature of this dependency can be specific to a given species or application.

The salts dissolved in the aqueous phase and the overall ionic strength of fluid within a porous medium can affect biomineralization rates. High salinity 
increases carbonate precipitation by ureolysis, depending on the bacterial species (Dupraz et al. 2009a,b; Harkes et al. 2010; Rusu et al. 2011). Salinity-dependent changes in mineral precipitation have been attributed to changes in ionic strength that, in turn, affect bacterial attachment to solid surfaces in the porous medium. Bacterial attachment is generally enhanced with higher salinity and ionic strength due to the decrease in repulsive electrostatic forces between bacteria and solid surfaces (Scholl et al. 1990; Foppen and Schijven 2006). A solution of $9 \mathrm{~g} \mathrm{~L}^{-1}$ of $\mathrm{NaCl}$ increased S. pasteurii attachment to solids by $30 \%$ compared to fresh water (Harkes et al. 2010), indicating stronger association of bacterial cells with surfaces and enhanced retention of bacteria in the porous medium. Biomineralization is controlled not only by the concentration of ions but also by the ion species present. Calcium carbonate nucleation takes longer as the ionic radii of background ions decreases (BurgosCara et al. 2017). The presence divalent cations has also been observed to affect calcite wettability. Calcite surfaces with $\mathrm{Sr}, \mathrm{Ba}$ or $\mathrm{Pb}$ are more hydrophobic, while calcite surfaces with $\mathrm{Mg}$ are more hydrophilic, which weakens organic compound adsorption and thus controls the growth and shape of mineral precipitate (Andersson et al. 2016).

The $\mathrm{pH}$ and redox conditions of the host matrix greatly influence microbial community composition and activity. From a chemical perspective, the formation of hydroxyl ions $\left(\mathrm{OH}^{-}\right)$as generated with ammonium ions $\left(\mathrm{NH}_{4}{ }^{+}\right)$during urea hydrolysis induces an alkaline environment (Eq. 1). Higher $\mathrm{pH}$ environments enhance carbonate precipitation (De Jong et al., 2010). Thus, the chemical process of biomineralization enhances further precipitation by increasing the local $\mathrm{pH}$ immediately surrounding bacterial cells (Rebata-Landa 2007). However, many bacterial species grow optimally at environmental $\mathrm{pH}$ values between 7 and 8 . As a result, while higher $\mathrm{pH}$ environments may chemically favor precipitation, these same environments may limit the abundance of microbes performing it. Furthermore, solution $\mathrm{pH}$ may alter the charge of bacterial cell surfaces, which contain zwitterions, and thus alter bacterial attachment and the distribution of cells within the porous medium.

In addition to $\mathrm{pH}$, the redox conditions are important to biomineralization pathways. Methane oxidation by sulfate-reducing bacteria (Eq. 5) produces calcite precipitation under anaerobic conditions only
(Cui et al. 2015). In the presence of dissolved metals, sulfate-reducing bacteria can also precipitate metal sulfides (Fortin et al. 1995; Kimber et al. 2020). In soils and aquifers, local redox conditions depend on oxygen diffusion, which is limited by hydration conditions (as oxygen transport is facilitated by the aqueous phase) and by the consumption of oxygen by plant roots and microorganisms. Redox conditions in soil often fluctuate in response to changes in the activity of microbial respiration pathways and the increase or decrease of different respiration products (Kuzyakov and Blagodatskaya 2015).

That said, some metabolic pathways - like urea hydrolysis (Eq. 1) - can produce calcite precipitates under aerobic and anaerobic conditions. Rates of calcite precipitation by B. sphaericus and S. pasteurii in anaerobic conditions were comparable to those in aerobic conditions, despite the lack of observable bacterial growth in anaerobic conditions (Mitchell et al. 2019). Thus, it appears that calcite precipitation by urea hydrolysis is not significantly affected by the absence of oxygen, at least in this system for the initial $24 \mathrm{~h}$ in culture (Mitchell et al. 2019).

Sediments and rocks are composed of diverse and spatially distributed parent minerals, the composition of which greatly influence biomineralization. For example, carbonate production by Myxococcus xanthus and Brevundimonas diminuta is strongly dependent on the mineralogy of the solid substrate. Placing either species on a calcium substrate stimulated tenfold greater cell density (cells $\mathrm{cm}^{-2}$ ) than on a silicate surface with a commensurate increase in carbonate production (Rodriguez-Navarro et al. 2012). In addition to substrate mineralogy, the presence of environmental contaminants in the host matrix can also alter the size and solubility of biomineralized precipitates. Strontium, for example, decreases carbonate biomineralization by $B$. pasteurii via ureolysis when present in the environment, likely reflecting a strontium-induced decrease in available active sites for nucleation and crystal growth. It is possible the large ionic radius of the $\mathrm{Sr}$ ion disrupts the sterics of the calcite lattice (Mitchell and Ferris, 2005, 2006).

Changes in physico-chemical properties also affect bacterial production of EPS, affecting the amount of available sites for mineral nucleation. Lower temperatures have been shown to alter bacterial growth and metabolism in a manner that increased the availability of precursors for EPS biosynthesis, thereby increasing 
EPS production (Gorret et al. 2001). Saline environments are favorable for microbial formation of $\mathrm{Mg}$ rich carbonates (Al Disi et al. 2019). Indeed, environmental shifts from low- to high- salinity has been shown to increase the fraction of carboxylic groups on EPS, suggesting that such shifts could increase the Mg-consuming precipitation of dolomite (Diloreto et al. 2021). At low pH, EPS from Bacillus megaterium shows a more dense and compact structure due to altered interactions of intermolecular hydrogen bonds (Wang et al. 2012a). Higher EPS and biofilm production by Lysinibacillus sp. YS11 (non-ureolytic metabolic pathway) in both aerobic and anaerobic conditions have been observed when calcium is provided in the medium, suggesting that EPS and biofilm formation are altered by MICP (Lee et al. 2017).

\subsection{The spatial context: complex and heterogeneous pore networks}

The chemical conditions discussed above occur in a host matrix of porous and fractured media with void spaces and fractures containing variable amounts of microbes, liquid and gaseous phases in variable spatial configurations. The spatial structure of the solid-void architecture and the presence of multiple phases fragment microbial aqueous habitats (Or et al. 2007) create a mosaic of fluid flow velocities, punctuated by preferential paths (high velocities) and stagnation zones (low velocities). Convection by fluid flow dominates chemical and particulate transport in certain porous systems, such as aquifers and wetlands. Thus, in determining flow patterns, solute mixing, and chemical dissolution between fluids and surfaces, the spatial heterogeneity of porous media exerts important effects on the activity of microorganisms, including biomineralization. Biochemical mineral precipitation and dissolution are highly sensitive to the distribution of water saturation and the porosity and permeability of the host matrix. For example, natural soils generally decrease in carbon content and oxygen with depth (Ebrahimi and Or 2016), transitioning from oxic to anoxic conditions with distance from the soil surface (Zhang and Furman 2021). A decrease in porosity and permeability or an increase in water saturation limits the diffusion of oxygen, promoting anoxic conditions and therefore biomineralization by anaerobic microbial communities.
Additionally, soils often have dynamic hydrologic regimes across dry-wet cycles. These meso- and microscale spatial variations present a major challenge for predictability of biomineralization in natural systems and the success of practical applications at meso- and field-scale, which generally desire uniform distributions of precipitate.

The degree of water saturation, being the fraction of the void space occupied by an aqueous phase, plays an important role in the spatial distribution of biologically precipitated minerals (Terzis and Laloui 2018). This is particularly true in natural examples of unsaturated porous media, in which water is preferentially retained in crevices, small pores and the sites of contact between grains. These regions thus exhibit increased biomineralization compared to regions without water (Cheng and Cord-Rywisch, 2012; Cheng et al. 2013), producing microscale heterogeneity in the distribution of mineral precipitate. Increasing the degree of water saturation increases the connectivity between pores and therefore accessibility of more regions to solutes and microorganisms. Nevertheless, even under fully liquid saturation conditions, homogeneous biomineralization is not guaranteed due to variable porosity within the host matrix.

Biomineralization is generally greater in regions of higher permeability, which have an increased ability to transport fluids (Dawoud et al. 2014a,b). Larger pores, such as macropores (voids larger than $75 \mu \mathrm{m}$ ), have been associated with deeper and broader areas of biomineralized precipitate (De Muynck et al. 2011). Likely, macropores are locations of preferential flow that can deliver more of the necessary components to favor biomineralization (Bundt et al. 2001). The effective porosity of the host matrix, being the connected fraction of void space within the total soil or rock volume, controls not only the accessibility of fluids (and dissolved nutrients and gases) to different spatial locations within the porous medium, but also the accessibility of microorganisms. The pore size distributions of natural soils and rocks can span from nanometers to centimeters, implying that a considerable fraction of the porous medium is inaccessible to microorganisms based on size exclusion (bacteria: $0.2-10 \mu \mathrm{m}$; fungal hyphae: $2-50 \mu \mathrm{m}$ ). Knowing the pore size distribution and connectivity of a host matrix can contribute to effective spatial control of biomineralization, by informing the selection of microorganisms for biomineralization applications and estimates 
of local variation in permeability within the host matrix.

The texture of a soil, being the size distribution of its primary particles or grains, also contributes to the spatial pattern of biomineralization. Studies in homogeneous porous media have found two limitations imposed by soil texture. First, very fine textures, despite having a larger solid specific surface area than coarse textures, hindered carbonate biomineralization due to their very low permeability. Second, coarsely textured soil, which has a high permeability and bacterial accessibility (Zhao et al. 2014), did not observe significant cementation of mineral precipitate when soil grains are very large (Rebata-Landa 2007). In heterogeneous fractured rock, aperture and roughness control permeability and therefore biomineralization rates and spatial patterns. Because fluid flow velocity in fractured media self-organizes into channels that remain stable, the biomineralized precipitate is distributed in the same manner as fluid flow (El Mountassir et al. 2014; Minto et al. 2016).

\subsection{The local ecology: temporal and spatial distribution of diverse bacteria}

The ecological implications of biomineralization and implications of local ecology on biomineralization remain an open area of research. It is thought that bacteria eventually become encapsulated by the precipitate (periplasmic encrustation), which limits nutrient and oxygen transfer and ultimately results in cell death, leaving bacteria-shaped "voids" within the bulk precipitate (Fig. 2c) (Tazaki et al. 2003; De Muynck et al. 2010; Cuthbert et al. 2013; Miot et al. 2015). However, some recent evidence suggests that cells and biofilms can detach from the mineral substrate during biomineral growth (Li et al. 2015; Bai et al. 2017). An improved understanding of whether cells die or migrate in these circumstances would serve to inform biomineralization models that consider the distribution of cells within a structured host matrix.

The distribution of single cells within porous media is far from uniform and most likely affects the spatial distribution of biomineralization products. Chemotaxis, the ability to sense and move towards a chemical source (Matthäus et al. 2009; Ahmed et al. 2010), enables bacteria to position themselves along gradients within a fully or partially saturated porous matrix
(Godány et al. 2017; Creppy et al. 2019; Ebrahimi and Or 2015; Scheidweiler et al. 2020). Chemotactic bacteria can accumulate in a region of high nutrient concentration and then disperse as the nutrient concentration is decreased by diffusion, flow or microbial metabolism. Such ephemeral pulses of bacterial density may determine the locations and rates of biomineralization.

The microorganisms hosted in porous media are subjected to environmental fluctuations both in space and time (Nguyen et al. 2020), affecting both microbial distributions and activity. Like chemotaxis, bacterial gene expression and metabolism can respond strongly to gradients and fluctuations in porous media (Nguyen et al. 2020). Sudden inputs of nutrient can induce soil bacteria to increase nutrient decomposition for hot moments of minutes to hours (Kuzyakov and Blagodatskaya 2015). Fluid flow can also lead to heterogeneity in gene expression by affecting local concentrations of autoinducers, molecules secreted by bacteria to coordinate biofilm formation based on bacterial population density (Kim et al. 2016). In environments with fluid flow, autoinducers accumulate at concentrations highest at the most downstream regions of a bacterial population (Kim et al. 2016). Thus, spatial heterogeneities in the host matrix can alter local biomineralization rates through affecting the spatial expression of traits like biofilm formation, which can influence biomineralization directly or indirectly by altering fluid flow.

Biofilm formation, a prominent trait in many microbial communities, affects the distribution and rates of biomineralization. Biofilms are dense microbial structures, composed of single or mixed species surrounded by a housing of extracellular polymeric substrates (EPS). Functional groups within the EPS have been observed to serve as initial nucleation sites or control the extent of precipitation and the morphology of precipitates (Braissant et al. 2003; Ercole et al. 2007; Decho 2010). Charge density has also been observed for inducing higher nucleation rates (Görgen et al., 2021). Thus, the spatial location of biomineralization in porous media likely depends on the location of biofilms, which are initiated at sites where bacteria attach to surfaces and dependent on chemical gradients (de Anna et al. 2020) and flow (Rusconi et al. 2014; Secchi et al. 2020). Variation in biofilm location and growth in turn contributes further pore-scale heterogeneities in fluid flow and chemistry (Drescher 


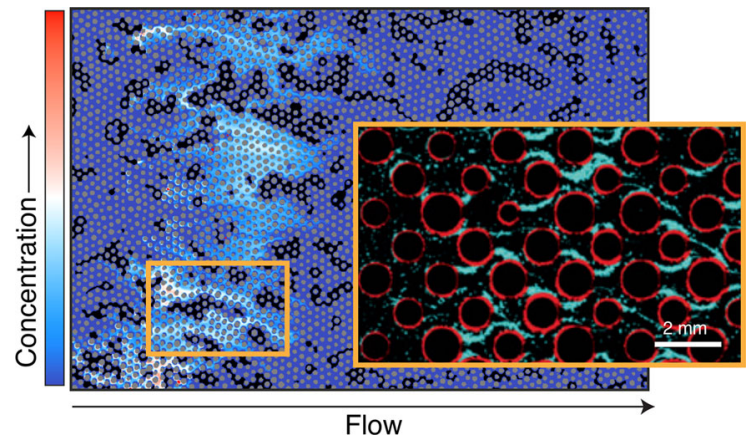

Fig. 3 An unsaturated porous media with solid grains (gray), a gas phase (black), liquid phase (dark blue) and chemical concentration gradients. Preferential paths emerge as fluid flow moves around the air pockets. Preferential paths correspond to regions of higher fluid flow velocities and higher chemical concentrations ( adapted from Jiménez-Martínez et al. 2017). Orange inset: The existence of concentration gradients and shear flow control the development of bacterial biofilms.

et al. 2013) (Fig. 3). Carbonates formed by biofilms are morphologically distinct from those produced under abiotic conditions ( $\mathrm{Li}$ et al. 2015), suggesting that biofilm architecture affects precipitate properties. Indeed, carbonate biomineralization appears to form primarily at the base of biofilms (Li et al. 2015). Altogether, biofilms present an excellent example of how the interplay between chemical, physical and biological processes at pore- and single cell-scales produce non-uniform biomineralization at the mesoscale.

\section{Controlling biomineralization processes in porous media}

Efforts to achieve spatial control over biomineralization at useful/application scales have focused on the manipulation of the microbes and/or the pore environment within the host matrix (Antwis et al. 2017). In certain applications, microorganisms capable of biomineralization may already be present in the host matrix (e.g., soil consolidation and stabilization, pollution remediation, ornamental stone consolidation), albeit at low abundance or under unfavorable conditions. In other applications (e.g., geological sequestration of $\mathrm{CO}_{2}$, enhanced oil recovery, concrete consolidation), native microorganisms may not be able to biomineralize under prevailing conditions. To overcome these two challenges, applications have sought to stimulate biomineralization: (i) by providing nutrients (biostimulators) to the existing microbial community or chemical amendments designed to select for dominant metabolic activity, (ii) by introducing specific microorganisms to augment native populations (bioaugmentation), or (iii) by a combination of both (Dhami et al. 2017). Together, these methods of enhanced biomineralization have been proposed as environmentally-friendly alternatives to the use of concrete, polymers or resins. Both methods inject solutions of prescribed composition into the host matrix, aiming to induce biomineralization in target regions and circumvent limitations due to uncontrolled bacterial activity or heterogeneous fluid flow and chemical transport. An understanding for how these injected solutions spread and mix with the resident fluids in a host matrix, and particularly how the injected solutions arrive to the microorganisms within the matrix, is key for successful spatial control of enhanced biomineralization strategies.

\subsection{Biochemical methods for enhancing specific biomineralization pathways}

The primary challenge of enhanced biomineralization is to promote the survival of desired microorganisms in desired locations under often suboptimal host matrix conditions. Current methods have sought to enable specific metabolic pathways or bacterial survivability, through a variety of injected inoculates.

\subsubsection{Considerations of metabolic pathway}

Biomineralization often occurs in extreme chemical and physical environments that stunt bacterial activity and growth. A potential solution for improving activity under suboptimal conditions, is to choose and introduce bacterial species tolerant of specific conditions. For example, desiccation-resistant and aerobic microorganisms, such as ureolytic bacteria and myxobacteria (e.g., Myxococcus xanthus), are well suited for near-surface applications, such as the consolidation of ornamental stones and soils (Rodriguez-Navarro et al. 2003; De Muynck et al. 2010; Jonkers and Schlangen 2009). However, oxygen availability limits the long-term use of aerobic microorganisms in deeper parts of geological formations (DeJong et al. 2013), for example, in geological 
sequestration of $\mathrm{CO}_{2}$ or enhanced oil recovery. Controlling the aerated locations is a potential engineering control for promoting an ecological niche for aerobic organisms in an anaerobic subsurface. Currently, injecting air, oxygen, or an oxygenated solution is technically difficult and expensive and remains an area of ongoing work.

Many subsurface applications focus on promoting anaerobic pathways for biomineralization, such as urea hydrolysis and, and more recently, denitrification. Carbonate precipitation by urea hydrolysis (Eq. 1) has been the most studied process for applications and is performed by some facultative anaerobes, such as $B$. pasteurii (Ferris et al. 1997). It is important to note, however, that while urea hydrolysis itself does not require oxygen, some MICP catalyzing organisms may still be sensitive to oxygen availability. Recently, the biomineralization of a prominent MICP model organism, S. pasteurii, was found to be inhibited under anoxic conditions (Martin et al. 2012). This finding has led to the exploration of denitrifying bacteria, such as Halomonas halodenitrificans, as microbial catalysts for carbonate precipitation (Martin et al. 2013).

\subsubsection{Bacterial growth and survivability}

Uncontrolled microbial growth is a recurrent challenge, as the overgrowth of microorganisms ultimately limits the long-term effectiveness of biomineralization applications. First, rapid overgrowth often leads to the accumulation of detrimental by-products, such as ammonia produced by urea hydrolysis (Eq. 1). Excessive ammonia leads to the eutrophication and acidification of ecosystems, amounting to toxic effects on humans, animals and vegetation. Ammonia can also discolor stone and is thus counterproductive in applications like ornamental stone consolidation (Sutton et al. 2009; Tobler et al. 2011). Second, uncontrolled microbial overgrowth also diminishes the spatial extent of biomineralization. In biostimulation, rapid growth can deplete the biostimulator before it can reach and induce biomineralization at further locations in the host matrix. Improved temporal control over the injection of biostimulator can enhance control over microbial growth by limiting nutrient availability over the course of application (Zhu and Dittrich 2016; Sect. 4.2). To control growth such that mineral precipitation can occur more uniformly over time and space, proposed bioaugmentation strategies include the use of inactive cells, such as lyophilized bacteria or spores, which can be viable for up to 200 years (Schlegel and Zaborosch 1993).

Uncontrolled undergrowth or cell death is another challenge, particularly in bioaugmentation. Microorganisms introduced to soils often decline in abundance or activity shortly after injection (van Veen et al. 1997). Several environmental factors can limit microbial survival and activity, including high pressure, high temperature, saline conditions, competition or predation from native organisms, and the extreme $\mathrm{pH}$ conditions often present in applications such as groundwater decontamination and enhanced oil recovery (Okwada and Li, 2010; Phillips et al. 2015). Some mesophilic bacteria, such as $S$. pasteurii, are recommended for biomineralization applications occurring at pressures up to $7.5 \mathrm{MPa}$ (Mitchell et al. 2013). $S$. pasteurii can also tolerate high salinities (Kuhlmann and Bremer 2002; Mortensen et al. 2011) and catalyzes carbonate precipitation in salinities below sea water (35 $\mathrm{g} \mathrm{L}^{-1}$ ) (Dupraz et al. 2009a). S. pasteurii is also a favorable species for concrete sealing applications, given its tolerance for high alkalinity and high $\mathrm{pH}(\sim 9)$ conditions (Mobley et al. 1995; Bang et al. 2001). However, pressures higher than $7.5 \mathrm{MPa}$ inhibit $S$. pasteurii DNA replication and protein synthesis, suppressing metabolic functions and growth (Abe et al. 1999). Thus, anaerobic denitrifiers such as $H$. halodenitrificans have been recommended for biomineralization applications when anoxic and high-pressure conditions coincide (Martin et al. 2013). Spores can also survive exposures to high pressure, such as those associated with injections of supercritical $\mathrm{CO}_{2}$ during geological sequestration, though chemical additives to the $\mathrm{CO}_{2}$ can reduce their viability (Zhang et al. 2006).

\subsubsection{Composition of injected inoculates and performance assessment}

Given the complexity of controlling microbial activity in porous media, in situ biostimulation or bioaugmentation remains experimental (El Fantroussi and Agathos 2005). Here, we highlight recent findings from controlled conditions that exemplify how the composition of an inoculum can be designed to enhance biomineralization. We first introduce the specific application of self-healing (pre-mixed 
inoculum) and then highlight more general strategies for the composition of injected inoculates.

Self-healing is a special application in that the host matrix, in particular concrete and mortar, can be preseeded with biomineralizing microorganisms in effort to achieve more uniform distribution of precipitate (Seifan et al. 2016; Castro-Alonso et al. 2019). To prepare a self-healing material, spores and other microorganisms with low metabolic activities and extremely long lifetimes can be added during the production of the concrete or mortar (Le MetayerLevrel et al. 1999; Sarkar et al., 2015; Zhang et al. 2017) and contribute to the long-term durability of the building material. Over time, the precipitates produced by these long-lasting microorganisms continue to maintain the structural integrity of the material within which they are embedded.

Two different self-healing techniques have been proposed: one directly introduces only bacteria to the material and the other immobilizes bacteria within "carriers" that are then mixed into the material. These carriers prevent bacterial movement within the host matrix and can be fabricated from a variety of materials. A recent study compared carriers made of silica gel and polyurethane and found that biomineralization by $B$. sphaericus was two-fold higher when carried by silica gel (Wang et al. 2012b). However, cracked mortar specimens containing polyurethane immobilized bacteria regained up to $60 \%$ more strength and were up to $10^{2}$ times less permeable than cracked mortar specimens containing bacteria in silica gel carriers. Experiments with Bacillus cohnii have also highlighted the effectiveness of carriers made from volcanic powders (e.g., perlite), completely healing crack widths up to $0.79 \mathrm{~mm}$ within 28 days (Zhang et al. 2017). Carriers made from expanded clays could fully heal cracks of smaller widths (0.45 mm).

Bacterial carriers have also been proposed for biomineralization applications requiring injected inoculates. Hydrogel encapsulation of biomineralizing microorganisms has been explored as a means of providing an advantage for introduced bacteria $(\mathrm{Wu}$ et al. 2017). For example, a hydrogel can physically protect bacteria from adverse conditions (El Fantroussi and Agathos 2005) or maintain a higher local concentration of nutrient (e.g., urea) around the bacteria to promote precipitation. The injection of a biostimulator metabolically available only to a co- injected bacterial strain can also provide a metabolic niche to the biomineralizer unused by native local microbiota, offering a potential solution for the longterm amendment of the host matrix with a desired biomineralizer (El Fantroussi and Agathos 2005).

Assessing the success of biomineralization applications is complicated in situ, but a variety of methods enable performance assessment in experimental settings. In the lab, assessment of urea hydrolysis can be performed by measuring the decomposition of urea or the production of ammonium, by visually or chemically measuring calcium carbonate, or by strength or waterproof testing the treated host matrix (Wang et al. 2012b; Wu et al. 2017). In the field, the survival of biomineralizers introduced to a soil may be assessed by targeted quantification of the abundance of the introduced bacteria by $16 \mathrm{~S}$ sequencing (El Fantroussi and Agathos 2005) or by measuring microbial community diversity (Dhami et al. 2017). Whole community monitoring represents an exciting next step in biomineralization applications, as recent work has begun to demonstrate that some biomineralizers (e.g., S. pasteurii) may have synergistic interactions with native organisms in the host matrix that increase carbonate precipitation (Dhami et al. 2017).

\subsection{Injection methods for controlling fluid flow and chemical transport}

Another strategy to spatially control biomineralization focuses on the how the chemical amendments and inoculates are injected, rather than the specific contents. Recent work has introduced temporal and spatial controls over injections, designed to facilitate the transport of reagents to circumvent undesirable patchiness in precipitate formation. The precipitation of surface scabs is a major limitation of shallow applications, such as the treatment of ornamental stone, and arises from the inability of the injected nutrient solution (i.e., urea in growth medium) to penetrate regions farther from the surface (Le Metayer-Levrel et al. 1999). Similarly, a recurrent problem in subsurface applications is the rapid precipitation of mineral around the injection site, plugging adjacent pores and fractures and preventing deeper penetration of the solution and decreasing biomineralization further from the injection site (Schultz et al. 2011). Lower injection rates with lower reactant concentrations in the injected solution have 
been demonstrated to improve precipitation efficiency and uniformity in biomineralization applications with S. pasteurii (Dawoud et al., 2009a, b; Al Qabany et al. 2012; Zambare et al. 2019). Similarly, injecting bacteria before injecting the cementation fluid produced a more homogeneous precipitate distribution than when both were injected simultaneously (Tobler et al. 2012). Still, controlling the local precipitation at the injection site remains an on-going challenge.

Pulsed injections have recently been proposed to reduce precipitation near the injection inlet. Indeed, the intermittent injection of a ureolytic treatment over recurring cycles has reduced the build-up of carbonate around inlets (Lauchnor et al. 2013; Hommel et al. 2016). It is thought that this pulsing maintains bacterial activity over several days while avoiding uncontrolled growth by interrupting longer no-flow periods of low positive mineral saturation index (SI), which determines whether mineral precipitates or stays in solution, with short high-flow periods, which deliver additional growth media and dissolved mineral (increasing SI). This temporal control over microbial activity enables biomineralization to occur further into the host matrix, improving the efficiency and spatial control.

Other injection designs make use of multiple injection inlets, patterning injections to control flow fields and ultimately the location of biomineralization. These multi-point injection designs perform various types of injections: single and multiphase injections, shallow and deep injections, and injections of low and high chemical concentrations (DeJong et al. 2013, 2014; Gomez et al. 2016, 2019; Nassar et al. 2018). By changing which inlets are actively injecting, multi-point injections can change the flow direction within individual pores, creating time-dependent flow fields that promote chemical spreading (Fig. 4). Changing flow fields can also recirculate nutrients around bacteria within the host matrix, shifting conditions towards those of a chemostat. Overall, multi-point injection designs have improved the spatial distribution of biomineralization (DeJong et al. 2014; Minto et al. 2019). Further improvements could be achieved by designing injection programs that produce chaotic mixing (Mays and Neupauer 2012; Neupauer et al. 2014), which would help the field overcome the topologically complex difficulties presented at small scale that currently limit spatial control over biomineralization at meso- and fieldscale.

\section{How modeling tools can guide biomineralization in porous and fractured media}

The spatio-temporal heterogeneity in the biological, chemical and hydraulic processes involved in biomineralization make its predictability extremely difficult. While laboratory experiments can provide information about the fundamental mechanisms that control dispersion, mixing and biochemical reactions in porous and fractured media (Kim et al. 2020), they are not able to simultaneously capture all relevant features of natural environments. In particular, individual experiments cannot account for the different types of heterogeneities, i.e., physical, chemical and biological, across different spatial scales (i.e., micrometers to kilometers) (Gelhar et al. 1992). Field-scale transport parameters can differ by orders of magnitude from the values estimated by laboratory experiments, which are by necessity performed on smaller scales (Weber et al. 1992; Vanderborght and Vereecken 2007). The inability to scale experimental results to field applications arises from the hydraulic, geochemical and microbial heterogeneity that exist at each scale and the fact that averaging biomineralization at a single scale (i.e., averaging within a representative elementary volume) cannot fully capture the process at other scales. Thus, the dependency on scale for accurate depictions of these heterogeneities in a porous medium is particularly critical when attempting to predict biomineralization.

To accurately predict biomineralization in heterogeneous porous and fractured media, models need to couple the various processes contributing to biomineralization. A few pore-scale models that consider microscale structure and implement some of the involved processes are found in the literature (Nogues et al. 2013; Qin et al. 2016). However, high computational costs limit the application of pore-scale models to larger scales. In fact, scaling up of biomineralization can be understood as the elimination of pore-scale processes by appropriate averaging of them. At the meso-scale, most of the existing models implement the complex reactions in water as a function of the equilibrium in the chemical system following the mass action law. For example, in urea 


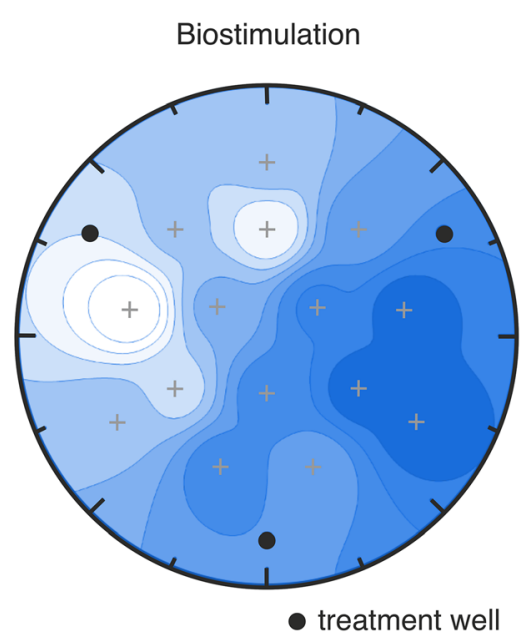

Fig. 4 Multi-point injection strategy. Biocementation experiments using a bioaugmentation approach with $S$. pasteurii and a biostimulation approach, which stimulated native ureolytic

hydrolysis, the calcite precipitation and dissolution are considered kinetically controlled (Barkouki et al. 2011; Martinez et al. 2014). However, these models do not account for the transport of bacteria and changes in physical or hydraulic properties (porosity and permeability). Models that currently consider changes in physical and hydraulic properties make important simplifications about the kinetic rates that control chemical reactions (Fauriel and Laloui 2012; Cuthbert et al. 2013; Wang and Nackenhorst 220) or assume an immobile and homogeneous distribution of bacteria (van Wijngaarden et al. 2011, 2013, 2016). In some of these works, the simplifications of the kinetics rates are carefully and rationally justified, exemplifying a notable form of upscaling (Fauriel and Laloui 2012). More complex models simultaneously consider multiphase flow, biofilm growth and changing ureolysis rates (Ebigbo et al. 2012; Hommel et al. 2015).

At the field-scale, the scarcity of spatially and temporally distributed information invites the maintenance of simple models, classically based on effective parameters (permeability, dispersivity) (Roden and Scheibe 2005; Cuthbert et al. 2013; Phillips et al. 2016; Cunningham et al. 2019). However, the high degree of heterogeneity and the existence of interfaces induce complex transport and mixing that cannot be captured by this smoothed representation. Fundamentally, these models cannot appropriately

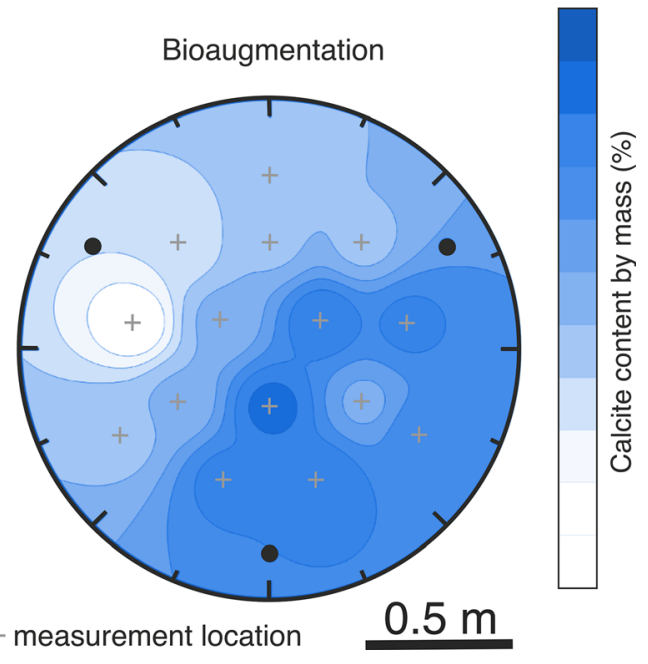

microorganisms to complete the process. Uniformity in the calcite content was not achieved in any of the approaches. Adapted from Gomez et al. (2016, 2019)

account for processes such as mixing and chemical reactions, which intrinsically occur at pore scale (Rolle et al. 2009; Williams et al. 2009; de Anna et al. 2014). Thus, while recent models are starting to couple the processes contributing to biomineralization and some upscaling attempts have been reported (DeJong et al. 2009; Terzis and Laloui 2019), the scaling up of biomineralization still presents a number of challenges to be addressed, such as bacterial attachment (Minto et al. 2019).

\section{Outlook}

Precise control over the spatial distribution of biomineralization in porous media requires holistic consideration of the spatial distribution of physical, chemical and biological factors. Generally, these factors create challenging heterogeneities, that fundamentally shape soils and subsurface ecological processes (Tecon and Or 2017), such as fragmented aqueous phases in unsaturated soils (Or et al. 2007), preferential flow paths that lead to non-uniform transport of nutrients (Le Borgne et al. 2013; Jiménez-Martínez et al. 2015), and highly localized gradients in oxygen and carbon (Borer et al. 2018). Advances in the field should account and systematically control for this complexity. 
5.1 Characterization of structure and processes in porous media

Combining recent advances can provide simultaneous quantitative measurements of the various factors and processes that control biomineralization (Robinson et al. 2008). Promising geophysical methods have enabled visualization of dynamic processes such as fluid dynamics and biogeochemical reactions within porous media (Binley et al. 2015). Electrical methods have characterized the physico-chemical environment, such as the spatial distribution of conductive (i.e., iron) (Atekwana and Aal 2015) and nonconductive minerals (i.e., calcite) (Wu et al. 2010). A minimally invasive technique has used spectral induced polarization to monitor the temporal evolution of urea hydrolysis and calcite precipitation in porous media (Zhang et al. 2012). Combining these methods with tracers that report on the metabolic activity of bacteria (Haggerty et al. 2009) are promising avenues by which biochemical reactions and mixing processes may be quantified in porous and fractured environments.

\subsection{Microbial activity in heterogeneous porous media}

An ongoing challenge is to understand how the spatial and temporal heterogeneity in porous media affect bacterial distribution and function. Pore-scale experiments and simulations have shown that bacterial growth varies considerably in space in the presence of chemical gradients (Knuston et al., 2005). We propose that future attention to how porous media affects motility range and bacterial migration and/or transport will inform efforts to control the spatial distribution of bacterial biomass and therefore biomineralization.

Attention should also be paid to the dynamics of bacterial biomineralization in the presence dynamic local environments. Minute-scale fluctuations in nutrient concentration have been experimentally shown to induce fluctuations in the growth rate of E. coli, leading to differences in net growth compared to steady environments of equal average nutrient availability (Nguyen et al. 2021). Similar fluctuations in porous media may change biomineralization rates over time (e.g., through changes in growth rate). It is also possible that diverse soil microorganisms may be less responsive to fluctuations. Communities in coastal sediments appear to have evolved the capacity to continuously denitrify, even as oxygen (generally a denitrification inhibitor) fluctuates around them (Marchant et al. 2017). Similarly, some soil communities have been found to grow faster (as seen by higher RNA to DNA ratios) when exposed to fluctuating conditions (oxic/anoxic) than to steady ones (steadily oxic or anoxic) (DeAngelis et al. 2010). How communities can maintain steady activity and growth under fluctuations may provide solutions for biomineralization applications that desire steady precipitation under difficult to control conditions.

\subsection{Genetic engineering or experimental evolution of microorganisms}

To achieve uniform biomineralization across meters or kilometers, a possible strategy could include the engineering of an organism that regulates biomineralization in a cell density-dependent manner. Bacterial quorum sensing systems, which mediate densitydependent gene expression, have already been manipulated to improve the treatment of wastewater and energy production from microbial fuel cells (Yong et al. 2015). Manipulating microbial activity such that higher cell densities, such as those occurring at injection inlets or in biofilms, coincide with lower single-cell biomineralization rates could help prevent uneven formation of precipitates, such as clogging at inlets.

Another possible avenue for spatial control could be the bioengineering of bacterial strains with enhanced dispersal capabilities, such as reduced attachment to surfaces and slower rates of surfaceattached colony growth. Reducing the number of cells within a surface-attached colony has been shown to increase the spatial range at which the human pathogen Pseudomonas aeruginosa colonizes its host (Laventie et al. 2018). Engineering biomineralizers to disperse more effectively through increased swimming speeds or tumbling rates could similarly spread the distribution of biomineralization throughout a host matrix. Strains of $E$. coli with enhanced motility have been evolved in soft agar environments that facilitate the selection of mutants that disperse the fastest $(\mathrm{Ni}$ et al. 2017).

Strains that are more genetically tractable can be metabolically engineered to catalyze specific biochemical reactions. $P$. aeruginosa MJK1 and E. coli 
MJK2 have previously been engineered to perform urea hydrolysis (Connolly et al. 2013). While respectively 4- and tenfold lower than the endogenous ureolytic activities of $S$. pasteurii, the engineered strains exhibited substantial ureolysis rate under standard laboratory growth conditions, but were able to grow 1.5- and twofold faster and to higher population densities. Genetically engineered sporeforming bacteria, such as the alkaliphilic B. subtilis, have been developed for self-healing applications (Sarkar et al., 2015). For applications of specific pH, candidate organisms include mutants of the fungus Aspergillus nidulans MAD1445 that can grow and promote calcium carbonate precipitation (Menon et al. 2019). For high temperature and hypersaline applications, strains isolated from hot springs and growing in highly saline environments offer initial candidates for engineered strains that tolerate and biomineralize in such conditions (Fouke 2011; Okumura et al. 2013).

\subsection{Abstracting and mimicking natural microenvironments}

For pore-scale studies, microfluidics represents a powerful tool to study biomineralization processes at the microscale. Microfluidics offers the ability to precisely control fluid flow and mimic natural microenvironmental conditions, while allowing optical observation and quantification (Schultz et al. 2011; Lauchnor et al. 2013; Yin et al. 2009; Singh et al. 2015). Classic microfluidic materials, such as glass and silicone (Rusconi et al., 2014; Son et al. 2015), may not contain many physico-chemical properties occurring in natural or engineered porous media (Aleklett et al. 2017). The inclusion of a mineral surface would offer the ability to perform microfluidic experiments with substrates that directly reproduce more natural conditions of asperity, wettability, porosity, and heterogeneity. So far, only a handful of devices have been developed to study fluid-solid reactions and mineral leaching (Satoh et al. 2007; Song et al. 2014; Ciceri and Allanore 2015; Osselin et al. 2016; Neuvulle et al., 2017; Jiménez-Martínez et al. 2020), or fluid dynamics (Porter et al. 2015; Singh et al. 2017). Adopting mineral microfluidics for biomineralization studies would enable experiments that include all fundamental characteristics that affect fluid flow, chemical reactions and microbial interactions at the fluid-solid interface.

\subsection{Achieving spatially controlled} biomineralization at the field scale

Mixing is a combination of stirring, which increases the interfacial area between the resident and the injected solution and creates concentration gradients, and diffusion, which smooths out the concentration gradients and homogenizes the concentration field. Stirring, in particular, can be controlled through designing fluid injection strategies to stimulate biomineralization in a spatially-controlled manner. Multi-point injection strategies can be used to stretch and fold the injected chemical plumes and further spread the inoculum into the host matrix (Mays and Neupauer 2012; Neupauer et al. 2014). Current multipoint injection applications tend to create encapsulating flows, which can isolate fluid zones for lengthy periods (Tefrey et al., 2012). However, mixing can be accelerated by designing injection programs that produce chaotic flows (Lester et al. 2016) (Fig. 5). The design of a multi-point injection program that mixes even in laminar flow conditions represents an immediate challenge that, if solved, can greatly improve our spatial control over biomineralization.

The tendency of bacteria to aggregate or attach near the inlet of injection sites remains a challenge, as it produces spatial heterogeneities in biomineralization applications. Sonication, the use of ultrasounds, have been demonstrated to efficiently produce bacterial suspensions without aggregates (Sanz et al. 2003) and without killing bacteria (Piyasena et al. 2003). Sonication prevents microbial biofilms (Wang et al. 2017) and can increase the rate of bacterial cell growth (Pitt and Ross, 2003). Ultrasonication is already used in soil and sediment remediation (Radu et al. 2020) and could serve as an environmentally friendly (no toxic chemicals are used or produced), low cost, and compact (allowing on-site treatment) solution to improve the spreading of inoculated bacteria across the host matrix (Pham et al. 2009).

Enhanced mixing in unsaturated porous media can be achieved by manipulating the degree of water saturation, which exerts strong control over solute mixing and chemical reactions (Jiménez-Martínez et al. 2015, 2017). When an injected suspension of bacteria and nutrients does not significantly change the degree of saturation, then the bacteria and nutrients in the injection travel through preferential paths in the host matrix. This produces a fingering pattern, and the 

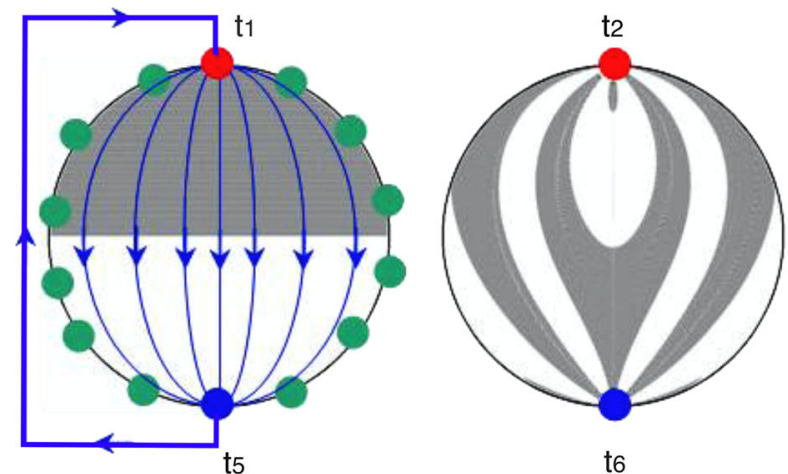

t6
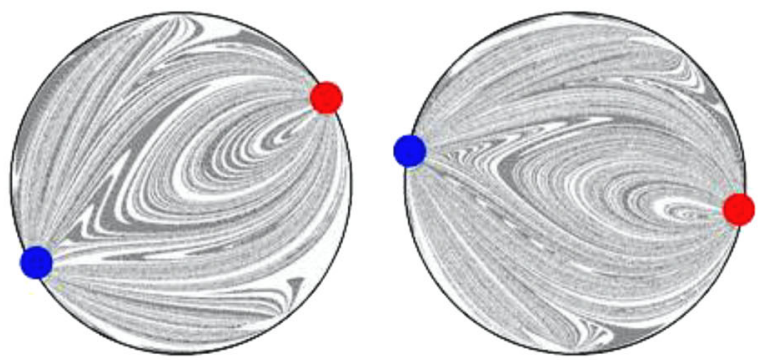

Fig. 5 Chaotic mixing in porous media spatially distributes a solution of nutrient and bacteria over time in an optimal stirring protocol. Flow from an injection well (red) to an extraction well (blue). If the time scale of biomineralization (i.e., kinetic) is

bacteria and nutrients are then unable to reach isolated clusters of water, resulting in patchy biomineralization due to incomplete mixing. If the water saturation of the porous host matrix is increased before or during injection, the accessibility of the porous media to bacteria and nutrient increases.

Some environments cannot be saturated. To enhance mixing in unsaturated environments, we propose two possibilities: (i) a simultaneous injection of an immiscible phase (e.g., air) to enhance mixing of the injected inoculum with the resident fluid (JiménezMartínez et al. 2016); and (ii) a forced desaturation (e.g., by evaporation) of an initially low concentration solution to concentrate the inoculum into several small water volumes (McLean et al. 1997). The latter proposition would still produce patchy mineralization, but in smaller patches that are more homogeneously distributed as controlled by the texture of the host matrix. t3

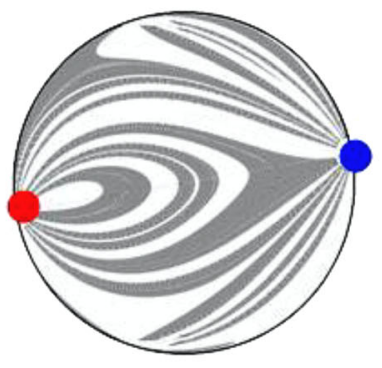

t7
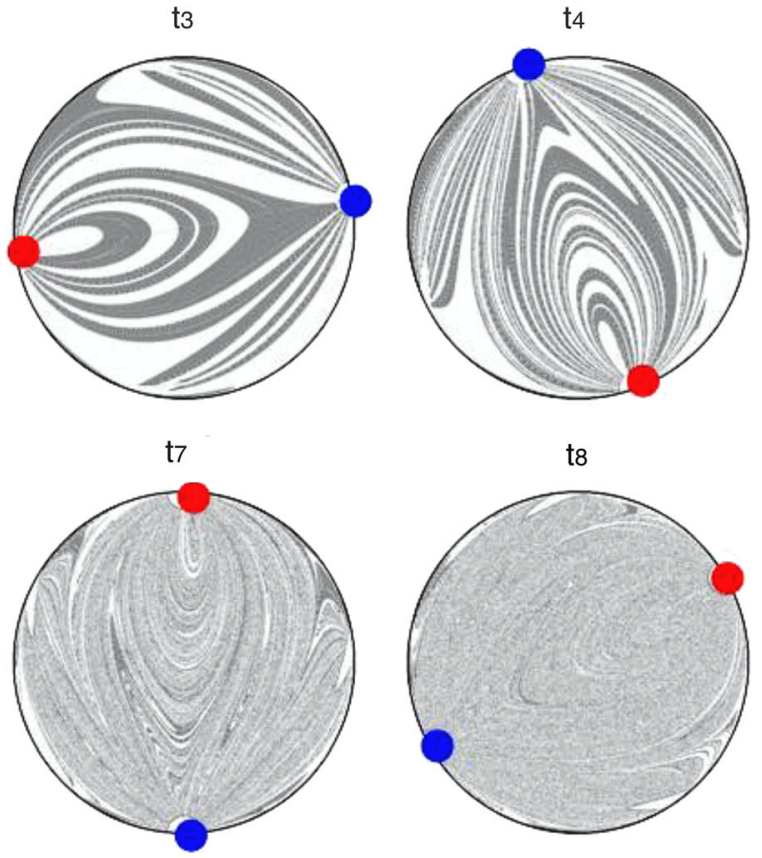

t8

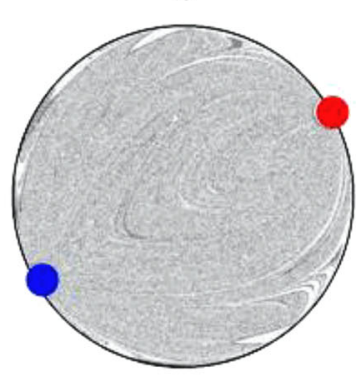

larger than the time needed to reach the well mixed conditions $\left(\mathrm{t}_{8}\right)$, a more homogeneous spatial distribution of precipitated could be obtained. Adapted from Lester et al. (2009)

\subsection{Harnessing the predictive power of numerical tools}

From a modelling perspective, the key challenge is the inclusion of the effects of pore-scale processes and bacterial behavior into multi-scale numerical models. The appropriate averaging of these small-scale processes would allow upscaling by eliminating the need to model them explicitly. Advection-dispersion model is commonly used in continuum models to simulate the transport of bacteria through porous media, and more recently, chemotaxis has been incorporated as an additional advection-like term (Adadevoh et al. 2017). However, this approach fails to predict the bacterial residence time and distribution in the host matrix, and therefore the rate of biologically-driven reactions. Furthermore, models typically employ simplified kinetics that do not account for cell density, $\mathrm{pH}$ effects or product inhibition. Thus, the reaction rate and therefore the mass of precipitate produced under natural conditions differs by orders of magnitude with respect to rates calculated under well-controlled laboratory conditions (i.e., batch experiments from which kinetics are measured). Because the rate of 
biomineralization changes in space and time, it is very difficult to know a priori. This fact reduces the predictive capacity of current numerical models. Recent advances in multispecies reactions modeling developed for geochemical purposes (Valdes-Abellan et al. 2017), along with new theories coupling complex fluid dynamics with transport processes in both fully and partially saturated porous media (e.g., lamellabased model) (Le Borgne et al. 2013, 2014, 2015; Jiménez-Martínez et al. 2017), inform about the mixing of nutrients and chemical amendments and provide a new opportunity to study and predict chemical heterogeneity at meso-scale. The models developed in the last decade for the transport of microorganisms (Creppy et al. 2019) and the growth of biofilms (Ezeuko et al. 2011) in porous media, as well as the biologically induced reactions and clogging processes (Thullner et al. 2002; Brovelli et al. 2009) will serve as the basis to complement and optimize the meso-scale models of biomineralization.

\section{Summary}

Biomineralization processes have been intertwined with the origins of life on Earth, as evident in the geologic record. An improved understanding of biomineralization processes in porous media requires a pore-scale integration of the physical and chemical micro-environments that contribute to its spatial heterogeneity. An improved understanding of how the spatial heterogeneity of porous media affects biomineralization would improve our interpretation of ancient and ongoing natural processes and promises for improved control over several technological applications that rely on biomineralization. Immediate challenges towards this perspective include an improved understanding of microbial behavior in heterogeneous microenvironments, using a pore-scale understand to inform the control of fluid mixing at field-scale, and the upscaling of microscale processes in predictive tools. By integrating these elements, we can then develop a predictive understanding of biomineralization in porous media, its rate and spatial distribution, in nature and in practice.

Acknowledgements The authors gratefully acknowledge financial support from the Swiss National Science Foundation granted to JJM (SNF, grant Nr. 200021_178986).
Funding Open access funding provided by Swiss Federal Institute of Technology Zurich.

Open Access This article is licensed under a Creative Commons Attribution 4.0 International License, which permits use, sharing, adaptation, distribution and reproduction in any medium or format, as long as you give appropriate credit to the original author(s) and the source, provide a link to the Creative Commons licence, and indicate if changes were made. The images or other third party material in this article are included in the article's Creative Commons licence, unless indicated otherwise in a credit line to the material. If material is not included in the article's Creative Commons licence and your intended use is not permitted by statutory regulation or exceeds the permitted use, you will need to obtain permission directly from the copyright holder. To view a copy of this licence, visit http://creativecommons.org/licenses/by/4.0/.

\section{References}

Abe F, Kato C, Horikoshi K (1999) Pressure-regulated metabolism in micro-organisms. Trends Microbiol 7:447-453

Achal V, Mukherjee A, Kumari D, Zhang Q (2015) Biomineralization for sustainable construction-a review of processes and applications. Earth Sci Rev 148:1-17

Adadevoh JS, Ostvar S, Wood B, Ford RM (2017) Modeling transport of chemotactic bacteria in granular media with distributed contaminant sources. Environ Sci Technol 51(24):14192-14198

Ahmed T, Shimizu TS, Stocker R (2010) Microfluidics for bacterial chemotaxis. Integr Biol 2:604-629

Al Disi ZA, Bontognali TR, Jaoua S, Attia E, Al-Kuwari HAS, Zouari N (2019) Influence of temperature, salinity and $\mathrm{Mg}^{2+}: \mathrm{Ca}^{2+}$ ratio on microbially-mediated formation of $\mathrm{Mg}$-rich carbonates by Virgibacillus strains isolated from a sabkha environment. Sci Rep 9(1):19633

Al Qabany A, Soga K, Santamarina C (2012) Factors affecting efficiency of microbially induced calcite precipitation. J Geotech Geoenviron Eng 138:992-1001

Aleklett K, Kiers ET, Ohlsson P, Shimizu TS, Caldas VE, Hammer EC (2017) Build your own soil: exploring microfluidics to create microbial habitat structures ISME J 14 , ismej2017184

Anbu P, Kang CH, Shin YJ, So JS (2016) Formations of calcium carbonate minerals by bacteria and its multiple applications. Springerplus 5(1):1-26

Andersson MP, Dideriksen K, Sakuma H, Stipp SLS (2016) Modelling how incorporation of divalent cations affects calcite wettability-implications for biomineralisation and oil recovery. Sci Rep 6:28854

Antwis RE, Griffiths SM, Harrison XA, Aranega-Bou P, Arce A, Bettridge AS, Brailsford FL, de Menezes A, Devaynes A, Forbes KM, Fry EL (2017) Fifty important research questions in microbial ecology. FEMS Microbiol Ecol. https://doi.org/10.1093/femsec/fix044

Ariyanti D, Handayani NA (2012) Feasibility of using microalgae for biocement production through 
biocementation. J Bioprocess Biotechniq. https://doi.org/ 10.4172/2155-9821.1000111

Atekwana EA, Aal GZA (2015) Iron biomineralization controls on geophysical signatures of hydrocarbon contaminated sediments. J Earth Sci 26(6):835-843

Atlas RC, Rude PD (1998) Complete oxidation of solid phase sulfides by manganese and bacteria in anoxic marine sediment. Geochim Cosmochim Acta 52:751-766

Bachmeier KL, Williams AE, Warmington JR, Bang SS (2002) Urease activity in microbiologically-induced calcite precipitation. J Biotechnol 93(2):171-181

Bai Y, Guo XJ, Li YZ, Huang T (2017) Experimental and visual research on the microbial induced carbonate precipitation by Pseudomonas aeruginosa. AMB Express 7(1):57. https://doi.org/10.1186/s13568-017-0358-5

Bains A, Dhami NK, Mukherjee A, Reddy MS (2015) Influence of exopolymeric materials on bacterially induced mineralization of carbonates. Appl Biochem Biotechnol 175(7):3531-3541

Bang SS, Galinat JK, Ramakrishnan V (2001) Calcite precipitation induced by polyurethane-immobilized Bacillus pasteurii. Enzyme Microbial Technol 28:404-409

Bao P, Xia M, Liu A, Wang M, Shen L, Yu R, Liu Y, Li J, Wu X, Fang C, Chen M (2018) Extracellular polymeric substances (EPS) secreted by Purpureocillium lilacinum strain Y3 promote biosynthesis of jarosite. RSC Adv 8(40):22635-22642

Barkouki TH, Martinez BC, Mortensen BM, Weathers TS, DeJong JD, Ginn TR, Spycher NF, Smith RW, Fujita Y (2011) Forward and inverse bio-geochemical modeling of microbially induced calcite precipitation in half-meter column experiments. Transport Porous Med 90:23-39

Bindschedler S, Cailleau G, Verrecchia E (2016) Role of fungi in the biomineralization of calcite. Minerals 6(2):41. https://doi.org/10.3390/min6020041

Binley A, Hubbard SS, Huisman JA, Revil A, Robinson DA, Singha K, Slater LD (2015) The emergence of hydrogeophysics for improved understanding of subsurface processes over multiple scales. Water Resour Res 51(6):3837-3866

Borer B, Tecon R, Or D (2018) Spatial organization of bacterial populations in response to oxygen and carbon countergradients in pore networks. Nat Commun 9(1):769

Braissant O, Cailleau G, Dupraz C, Verrecchia EP (2003) Bacterially induced mineralization of calcium carbonate in terrestrial environments: the role of exopolysaccharides and amino acids. J Sediment Res 73(3):485-490

Brovelli A, Malaguerra F, Barry DA (2009) Bioclogging in porous media: model development and sensitivity to initial conditions. Environ Modell Softw 24:611-626

Brussaard L (1997) Biodiversity and ecosystem functioning in soil. Ambio 26(8):563-570

Bundt M, Widmer F, Pesaro M, Zeyer J, Blaser P (2001) Preferential flow paths: biological 'hot spots' in soils. Soil Biol Biochem 33(6):729-738

Burbank MB, Weaver TJ, Green TL, Williams BC, Crawford RL (2011) Precipitation of calcite by indigenous microorganisms to strengthen liquefiable soils. Geomicrobiol J 28(4):301-312

Burgos-Cara A, Putnis CV, Rodriguez-Navarro C, Ruiz-Agudo E (2017) Hydration effects on the stability of calcium carbonate pre-nucleation species. Minerals 7(7):126. https://doi.org/10.3390/min7070126

Castro-Alonso MJ, Montañez-Hernandez LE, Sanchez-Muñoz MA, Macias Franco MR, Narayanasamy R, Balagurusamy N (2019) Microbially induced calcium carbonate precipitation (MICP) and its potential in bioconcrete: microbiological and molecular concepts. Front Mater. https://doi. org/10.3389/fmats.2019.00126

Chekroun KB, Rodríguez-Navarro C, González-Muñoz MT, Arias JM, Cultrone G, Rodríguez-Gallego M (2004) Precipitation and growth morphology of calcium carbonate induced by Myxococcus xanthus: implications for recognition of bacterial carbonates. J Sediment Res 74(6):868-876

Cheng L, Cord-Ruwisch R (2012) In situ soil cementation with ureolytic bacteria by surface percolation. Ecol Eng 42:64-72

Cheng L, Cord-Ruwisch R, Shahin MA (2013) Cementation of sand soil by microbially induced calcite precipitation at various degrees of saturation. Can Geotech J 50(1):81-90

Cheng L, Shahin MA, Cord-Ruwisch R, Addis M, Hartanto T, Elms C (2014) Soil stabilisation by microbial-induced calcite precipitation (MICP): investigation into some physical and environmental aspects Proceedings of the 7th International Congress on Environmental Geotechnics 2014 Melbourne Australia 1105-1112

Chou CW, Seagren EA, Aydilek AH, Lai M (2011) Biocalcification of sand through ureolysis. J Geotech Geoenviron 137(12):1179-1189

Chu J, Stabnikov V, Ivanov V (2012) Microbially induced calcium carbonate precipitation on surface or in the bulk of soil. Geomicrobiol J 29(6):544-549

Ciceri D, Allanore A (2015) Microfluidic leaching of soil minerals: release of $\mathrm{K}+$ from $\mathrm{K}$ feldspar. PLoS ONE 10:e0139979

Connolly J, Kaufman M, Rothman A, Gupta R, Redden G, Schuster M, Colwell F, Gerlach R (2013) Construction of two ureolytic model organisms for the study of microbially induced calcium carbonate precipitation. J Microbiol Methods 94(3):290-299

Connolly JM, Jackson B, Rothman AP, Klapper I, Gerlach R (2015) Estimation of a biofilm-specific reaction rate: kinetics of bacterial urea hydrolysis in a biofilm. NPJ Biofilms Microbiomes 1:15014

Creppy A, Clément E, Douarche C, D’Angelo MV, Auradou H (2019) Effect of motility on the transport of bacteria populations through a porous medium. Phys Rev Fluids 4(1):013102

Cui M, Ma A, Qi H, Zhuang X, Zhuang G (2015) Anaerobic oxidation of methane: an "active" microbial process. MicrobiologyOpen 4(1):1-11

Cunningham AB, Gerlach R, Spangler L, Mitchell AC (2009) Microbially enhanced geologic containment of sequestered supercritical $\mathrm{CO}_{2}$. Energy Procedia 1(1):3245-3252

Cunningham AB, Class H, Ebigbo A, Gerlach R, Phillips AJ, Hommel J (2019) Field-scale modeling of microbially induced calcite precipitation. Comput Geosci 23:399-414. https://doi.org/10.1007/s10596-018-9797-6

Cuthbert MO, Riley MS, Handley-Sidhu S, Renshaw JC, Tobler DJ, Phoenix VR, Mackay R (2012) Controls on the rate of ureolysis and the morphology of carbonate precipitated by 
S. Pasteurii biofilms and limits due to bacterial encapsulation. Ecol Eng 41:32-40

Cuthbert MO, McMillan LA, Handley-Sidhu S, Riley MS, Tobler DJ, Phoenix VR (2013) A field and modeling study of fractured rock permeability reduction using microbially induced calcite precipitation. Environ Sci Technol 47:13637-13643. https://doi.org/10.1021/es402601g

Dawoud O, Chen CY, Soga K (2014a) Microbial induced calcite precipitation for geotechnical and environmental applications In New Frontiers in Geotechnical Engineering Zhang G, Liu Z (Eds) GPS 243: 2014 pp 11-18

Dawoud O, Chen CY, Soga K (2014b) Microbial-induced calcite precipitation (MICP) using surfactants In Geo-Congress 2014: Geo-characterization and Modeling for Sustainability Abbu-Farsakh M, Yu X, Hoyos LR Eds GSP 234: 2014, pp 1635-1643

de Anna P, Jimenez-Martinez J, Tabuteau H, Turuban R, Le Borgne T, Derrien M, Méheust Y (2014) Mixing and reaction kinetics in porous media: an experimental pore scale quantification. Environ Sci Technol 48(1):508-516

de Anna P, Pahlavan AA, Yawata Y, Stocker R, Juanes R (2020) Chemotaxis under flow disorder shapes microbial dispersion in porous media. Nat Phys. https://doi.org/10.1038/ s41567-020-1002-x

De Muynck W, De Belie N, Verstraete W (2010) Microbial carbonate precipitation in construction materials: a review. Ecol Eng 36(2):118-136

De Muynck W, Leuridan S, Van Loo D, Verbeken K, Cnudde V, De Belie N, Verstraete W (2011) Influence of pore structure on the effectiveness of a biogenic carbonate surface treatment for limestone conservation. Appl Environ Microbiol 77(19):6808-6820

De Muynck W, Verbeken K, De Belie N, Verstraete W (2013) Influence of temperature on the effectiveness of a biogenic carbonate surface treatment for limestone conservation. Appl Microbial Biotechnol 97(3):1335-1347

DeAngelis KM, Silver WL, Thompson AW, Firestone MK (2010) Microbial communities acclimate to recurring changes in soil redox potential status. Environ Microbiol 12(12):3137-3149

Decho AW (2010) Overview of biopolymer-induced mineralization: what goes on in biofilms? Ecol Eng 36(2):137-144

DeJong JT, Mortensen BM, Martinez BC, Nelson DC (2010) Bio-mediated soil improvement. Ecol Eng 36(2):197-210

DeJong J, Soga K, Kavazanjian E, Burns S, Van Paassen L, Al Quabany A et al (2013) Biogeochemical processes and geotechnical applications: progress, opportunities and challenges. Geotechnique 63:287-301

DeJong JT, Martinez BC, Ginn TR, Hunt C, Major D, Tanyu B (2014) Development of a scaled repeated five-spot treatment model for examining microbial induced calcite precipitation feasibility in field applications. Geotech Test $\mathbf{J}$ 37(3):424-435

DeJong JT, Martinez BC, Mortensen BM, Nelson DC, Waller JT, Weil MH, Ginn TR, Weathers T, Barkouki T, Fujita Y, Redden G (2009) Upscaling of bio-mediated soil improvement (No. INL/CON-09-15487) Idaho National Laboratory (INL)

Dhami NK, Reddy MS, Mukherjee A (2013) Biomineralization of calcium carbonates and their engineered applications: a review. Front Microbiol. https://doi.org/10.3389/fmicb. 2013.00314

Dhami NK, Alsubhi WR, Watkin E, Mukherjee A (2017) Bacterial community dynamics and biocement formation during stimulation and augmentation: implications for soil consolidation. Front Microbiol. https://doi.org/10.3389/ fmicb.2017.01267

Diloreto ZA, Garg S, Bontognali TR, Dittrich M (2021) Modern dolomite formation caused by seasonal cycling of oxygenic phototrophs and anoxygenic phototrophs in a hypersaline sabkha. Sci Rep 11(1):4170

Drescher K, Shen Y, Bassler BL, Stone HA (2013) Biofilm streamers cause catastrophic disruption of flow with consequences for environmental and medical systems. Proc Natl Acad Sci 111(15):5622-5627. https://doi.org/10. 1073/pnas.1318943111

Dupraz S, Menez B, Gouze P, Leprovost R, Benezeth P, Pokrovsky O, Guyot F (2009a) Experimental approach of $\mathrm{CO}_{2}$ biomineralization in deep saline aquifers. Chem Geol 265:54-62

Dupraz S, Parmentier M, Menez B, Guyot F (2009b) Experimental and numerical modeling of bacterially induced $\mathrm{pH}$ increase and calcite precipitation in saline aquifers. Chem Geol 265:44-53

Ebigbo A, Phillips A, Gerlach R, Helmig R, Cunningham AB, Class H, Spangler LH (2012) Darcy-scale modeling of microbially induced carbonate mineral precipitation in sand columns. Water Resour Res. https://doi.org/10.1029/ 2011WR011714

Ebrahimi A, Or D (2015) Hydration and diffusion processes shape microbial community organization and function in model soil aggregates. Water Resour Res 51(12):9804-9827

Ebrahimi A, Or D (2016) Microbial community dynamics in soil aggregates shape biogeochemical gas fluxes from soil profiles-upscaling an aggregate biophysical model. Glob Change Biol 22(9):3141-3156

Ehrlich HL (1996) How microbes influence mineral growth and dissolution. Chem Geol 132:5-9

Ehrlich HL (1998) Geomicrobiology: its significance for geology. Earth Sci Rev 45(1-2):45-60

El Fantroussi S, Agathos SN (2005) Is bioaugmentation a feasible strategy for pollutant removal and site remediation? Curr Opin Microbiol 8(3):268-275

El Mountassir GE, Lunn RJ, Moir H, MacLachlan E (2014) Hydrodynamic coupling in microbially mediated fracture mineralization: formation of self-organized groundwater flow channels. Water Resour, Res 50(1):1-16

Ercole C, Cacchio P, Botta AL, Centi V, Lepidi A (2007) Bacterially induced mineralization of calcium carbonate: the role of exopolysaccharides and capsular polysaccharides. Microsc Microanal 13(1):42-50

Erşan YÇ, De Belie N, Boon N (2015) Microbially induced $\mathrm{CaCO}_{3}$ precipitation through denitrification: an optimization study in minimal nutrient environment. Biochem Eng $\mathrm{J}$ 101:108-118

Ezeuko CC, Sen A, Grigoryan A, Gates ID (2011) Pore-network modeling of biofilm evolution in porous media. Biotechnol Bioeng 108(10):2413-2423 
Fauriel S, Laloui L (2012) A bio-chemo-hydro-mechanical model for microbially induced calcite precipitation in soils. Comput Geotech 46:104-120

Ferris F, Stehmeier L, Kantzas A, Mourits F (1997) Bacteriogenic mineral plugging. J Can Pet Technol 36:56-61. https://doi.org/10.2118/97-09-07

Ferris FG, Phoenix V, Fujita Y, Smith RW (2004) Kinetics of calcite precipitation induced by ureolytic bacteria at 10 to $20 \mathrm{C}$ in artificial groundwater. Geochim Cosmochim Acta 68(8):1701-1710

Flemming HC et al (2016) The perfect slime: microbial extracellular polymeric substances (EPS)

Foppen JWA, Schijven JF (2006) Evaluation of data from the literature on transport and survival of Escherichia coli and thermotolerant coliforms in aquifers under saturated conditions. Water Res 40(3):401-426

Fortin D, Davis B, Southam G, Beveridge TJ (1995) Biogeochemical phenomena induced by bacteria within sulfidic mine tailings. J Ind Microbiol 14(2):178-185

Fouke BW (2011) Hot-spring systems geobiology: abiotic and biotic influences on travertine formation at Mammoth hot springs, Yellowstone National Park, USA. Sedimentology 58:170-219

Fridjonsson EO, Seymour JD, Schultz LN, Gerlach R, Cunningham AB, Codd SL (2011) NMR measurement of hydrodynamic dispersion in porous media subject to biofilm mediated precipitation reactions. J Contam Hydrol 120:79-88

Gadd GM (2010) Metals, minerals and microbes: geomicrobiology and bioremediation. Microbiology 156(3):609-643

Gahlawat G, Choudhury AR (2019) A review on the biosynthesis of metal and metal salt nanoparticles by microbes. RSC Adv 9(23):12944-12967

Ganendra G, De Muynck W, Ho A, Arvaniti EC, Hosseinkhani B, Ramos JA, Rahier H, Boon N (2014) Formate oxidationdriven calcium carbonate precipitation by Methylocystis parvus OBBP. Appl Environ Microbiol 80(15):4659-4667

Gavrilescu M, Pavel LV, Cretescu I (2009) Characterization and remediation of soils contaminated with uranium. J Hazard Mater 163(2-3):475-510

Gelhar LW, Welty C, Rehfeldt KR (1992) A critical review of data on field-scale dispersion in aquifers. Water Resour Res 28(7):1955-1974

Ghosh T, Bhaduri S, Montemagno C, Kumar A (2019) Sporosarcina pasteurii can form nanoscale calcium carbonate crystals on cell surface. PLoS ONE 14(1):e0210339. https://doi.org/10.1371/journal.pone.0210339

Godány M, Khatri BS, Goldstein RA (2017) Optimal chemotactic responses in stochastic environments. PLoS ONE 12(6): 0179111

Gomez MG, Anderson CM, Graddy CM, DeJong JT, Nelson DC, Ginn TR (2016) Large-scale comparison of bioaugmentation and biostimulation approaches for biocementation of sands. J Geotech Geoenviron Eng 143(5):04016124

Gomez MG, Graddy CM, DeJong JT, Nelson DC (2019) Biogeochemical changes during bio-cementation mediated by stimulated and augmented ureolytic microorganisms. Sci Rep 9(1):1-15

Gorbushina AA (2007) Life on the rocks. Environ Microbiol 9:1613-1631
Görgen S, Benzerara K, Skouri-Panet F, Gugger M, Chauvat F, Cassier-Chauvat C (2021) The diversity of molecular mechanisms of carbonate biomineralization by bacteria. Discover Materials 1(1):1-20

Gorret N, Maubois JL, Engasser JM, Ghoul M (2001) Study of the effects of temperature, $\mathrm{pH}$ and yeast extract on growth and exopolysaccharides production by Propionibacterium acidi-propionici on milk microfiltrate using a response surface methodology. J Appl Microbiol 90(5):788-796

Hammes F, Verstraete W (2002) Key roles of pH and calcium metabolism in microbial carbonate precipitation. Rev Environ Sci Bio 1(1):3-7

Han Z, Cheng X, Ma Q (2016) An experimental study on dynamic response for MICP strengthening liquefiable sands. Earthq Eng Eng Vib 15(4):673-679

Han Z, Wang J, Zhao H, Tucker ME, Zhao Y, Wu G, Zhou J, Yin J, Zhang H, Zhang X, Yan H (2019) Mechanism of biomineralization induced by Bacillus subtilis $\mathrm{J} 2$ and characteristics of the biominerals. Minerals 9(4):218. https://doi.org/10.3390/min9040218

Harkes MP, Van Paassen LA, Booster JL, Whiffin VS, van Loosdrecht MC (2010) Fixation and distribution of bacterial activity in sand to induce carbonate precipitation for ground reinforcement. Ecol Eng 36(2):112-117

Heim (2011) An integrated approach to the study of biosignatures in mineralizing biofilms and microbial mats

Hommel J, Lauchnor E, Phillips A, Gerlach R, Cunningham AB, Helmig R, Ebigbo A, Class H (2015) A revised model for microbially induced calcite precipitation: improvements and new insights based on recent experiments. Water Resour Res 51:3695-3715

Hommel J, Lauchnor E, Gerlach R, Cunningham AB, Ebigbo A, Helmig R, Class H (2016) Investigating the influence of the initial biomass distribution and injection strategies on biofilm-mediated calcite precipitation in porous media. Transport Porous Med 114(2):557-579

Ivanov V, Chu J (2008) Applications of microorganisms to geotechnical engineering for bioclogging and biocementation of soil in situ. Rev Environ Sci Biotechnol 7(2):139-153

Jiménez-López C, Rodriguez-Navarro C, Piñar G, CarrilloRosúa FJ, Rodriguez-Gallego M, Gonzalez-Muñoz MT (2007) Consolidation of degraded ornamental porous limestone stone by calcium carbonate precipitation induced by the microbiota inhabiting the stone. Chemosphere 68(10):1929-1936

Jiménez-Martínez J, de Anna P, Tabuteau H, Turuban R, Le Borgne T, Méheust Y (2015) Pore scale mechanisms for the enhancement of mixing in unsaturated porous media and implications for chemical reactions. Geophys Res Lett 42(13):5316-5324

Jiménez-Martínez J, Porter ML, Hyman JD, Carey JW, Viswanathan HS (2016) Mixing in a three-phase system: enhanced production of oil-wet reservoirs by $\mathrm{CO}_{2}$ injection. Geophys Res Lett 43(1):196-205. https://doi.org/10. 1002/2015GL066787

Jiménez-Martínez J, Le Borgne T, Tabuteau H, Méheust Y (2017) Impact of saturation on dispersion and mixing in porous media: photo-bleaching pulse injection experiments and shear-enhanced mixing model. Water Resour Res 53(2):1457-1472 
Jiménez-Martínez J, Hyman JD, Chen Y, Carey JW, Porter ML, Kang Q, Guthrie G, Viswanathan HS (2020) Homogeneization of dissolution and enhanced precipitation induced by bubbles in multiphase flow systems. Geophys Res Lett 47(7):e2020GL087163. https://doi.org/10.1029/ 2020GL087163

Johnson DB (2014) Biomining—biotechnologies for extracting and recovering metals from ores and waste materials. Curr Opin Biotechnol 30:24-31

Jonkers HM, Schlangen E (2009) A two component bacteria based self healing concrete. Concr Repair Rehabil Retrofit $1: 119-120$

Keiner R, Gruselle MC, Michalzik B, Popp J, Frosch T (2015) Raman spectroscopic investigation of $13 \mathrm{CO} 2$ labeling and leaf dark respiration of Fagus sylvatica L (European beech). Anal Bional Chem 407(7):1813-1817

Keren-Paz A, Brumfeld V, Oppenheimer-Shaanan Y, KolodkinGal I (2018) Micro-CT X-ray imaging exposes structured diffusion barriers within biofilms. NPJ Biofilms Microbiomes 4(1):1-4. https://doi.org/10.1038/s41522-0180051-8

Kim MK, Ingremeau F, Zhao A, Bassler BL, Stone HA (2016) Local and global consequences of flow on bacterial quorum sensing. Nat Microbiol 1(1):1-5

Kim DH, Mahabadi N, Jang J, van Paassen LA (2020) Assessing the kinetics and pore-scale characteristics of biological calcium carbonate precipitation in porous media using a microfluidic chip experiment. Water Resour Res 56:e2019WR025420. https://doi.org/10.1029/ 2019WR025420

Kimber RL, Bagshaw H, Smith K, Buchanan DM, Coker VS, Cavet JS, Lloyd JR (2020) Biomineralization of $\mathrm{Cu}_{2} \mathrm{~S}$ nanoparticles by Geobacter sulfurreducens. Appl Environ Microbiol 86(18):e00967-e1020

Knorre HV, Krumbein WE (2000) Bacterial calcification. Micro Sedi PP. 25-31

Knutson CE, Werth CJ, Valocchi AJ (2005) Pore-scale simulation of biomass growth along the transverse mixing zone of a model two-dimensional porous medium. Water Resour Res 41:W07007. https://doi.org/10.1029/2004WR003459

Kuhlmann AU, Bremer E (2002) Osmotically regulated synthesis of the compatible solute ectoine in Bacillus pasteurii and related Bacillus spp. Appl Environ Microbiol 68:772-783

Kuzyakov Y, Blagodatskaya E (2015) Microbial hotspots and hot moments in soil: concept \& review. Soil Bio Biochem 83:184-199

Lauchnor EG, Schultz LN, Bugni S, Mitchell AC, Cunningham AB, Gerlach R (2013) Bacterially induced calcium carbonate precipitation and strontium coprecipitation in a porous media flow system. Environ Sci Technol 47(3):1557-1564

Lauchnor EG, Topp DM, Parker AE, Gerlach R (2015) Whole cell kinetics of ureolysis by Sporosarcina pasteurii. J Appl Microbiol 118(6):1321-1332

Laventie BJ, Sanger M, Estermann F, Manfredi P, Planes R, Hug I, Jaeger T, Meunier E, Broz P, Jenal U (2018) A surfaceinduced asymmetric program promotes tissue colonization by Pseudomonas aeruginosa. Cell Host Microbe 25(1):140-152. https://doi.org/10.1016/j.chom.2018.11. 008
Le Borgne T, Dentz M, Villermaux E (2013) Stretching, coalescence, and mixing in porous media. Phys Rev Lett 110(20):204501

Le Borgne TL, Ginn TR, Dentz M (2014) Impact of fluid deformation on mixing-induced chemical reactions in heterogeneous flows. Geophys Res Lett 41(22):7898-7906

Le Borgne T, Dentz M, Villermaux E (2015) The lamellar description of mixing in porous media. J Fluid Mech 770:458-498

Le Metayer-Levrel G, Castanier S, Orial G, Loubiere JF, Perthuisot JP (1999) Applications of bacterial carbonatogenesis to the protection and regeneration of limestones in buildings and historic patrimony. Sediment Geol 126(1-4):25-34

Lee YS, Kim HJ, Park W (2017) Non-ureolytic calcium carbonate precipitation by Lysinibacillus sp YS11 isolated from the rhizosphere of Miscanthus sacchariflorus. J Microbiol 55(6):440-447

Lester DR, Metcalfe G, Trefry MG, Ord A, Hobbs B, Rudman M (2009) Lagrangian topology of a periodically reoriented potential flow: Symmetry, optimization, and mixing. Phys Rev E 80(3):036208

Lester DR, Dentz M, Le Borgne T (2016) Chaotic mixing in three-dimensional porous media. J Fluid Mech 803:144-174

Li X, Chopp DL, Russin WA, Brannon PT, Parsek MR, Packman AI (2015) Spatial patterns of carbonate biomineralization in biofilms. Appl Environ Microbiol 81(21):7403-7410

Li M, Cheng X, Guo H, Yang Z (2016) Biomineralization of carbonate by Terrabacter tumescens for heavy metal removal and biogrouting applications. J Environ Eng 142(9):C4015005

Lian B, Hu Q, Chen J, Ji J, Teng HH (2006) Carbonate biomineralization induced by soil bacterium Bacillus megaterium. Geochim Cosmochim Acta 70(22):5522-5535

Liang X, Hillier S, Pendlowski H, Gray N, Ceci A, Gadd GM (2015) Uranium phosphate biomineralization by fungi. Environ Microbiol 17(6):2064-2075

Lu N, Massoudieh A, Liang X, Kamai T, Zilles JL, Nguyen TH, Ginn TR (2015) A kinetic model of gene transfer via natural transformation of Azotobacter vinelandii. Environ Sci Wat Res 1(3):363-374

Mann S (2000) The chemistry of form. Angew Chem Int Ed 39:3393-3406

Marchant HK, Ahmerkamp S, Lavik G, Tegetmeyer HE, Graf J, Klatt JM, Holtappels M, Walpersdorf E, Kuypers MM (2017) Denitrifying community in coastal sediments performs aerobic and anaerobic respiration simultaneously. ISME J 11(8):1799-1812

Martin D, Dodds K, Ngwenya B, Butler I, Elphick S (2012) Inhibition of Sporosarcina pasteurii under anoxic conditions: implications for subsurface carbonate precipitation and remediation via ureolysis. Environ Sci Technol 46:8351-8355

Martin D, Dodds K, Butler IB, Ngwenya BT (2013) Carbonate precipitation under pressure for bioengineering in the anaerobic subsurface via denitrification. Environ Sci Technol 47:8692-8699 
Martinez BC, DeJong JT, Ginn TR (2014) Bio-geochemical reactive transport modeling of microbial induced calcite precipitation to predict the treatment of sand in one dimensional flow. Comput Geotech 58:1-13. https://doi. org/10.1016/j.compgeo.2014.01.013

Matthäus F, Jagodič M, Dobnikar J (2009) E coli superdiffusion and chemotaxis-search strategy precision and motility. Biophys J 97(4):946-957

Mays DC, Neupauer RM (2012) Plume spreading in groundwater by stretching and folding. Water Resour Res 48:W07501. https://doi.org/10.1029/2011WR011567

McConnaughey TA, Whelan JF (1997) Calcification generates protons for nutrient and bicarbonate uptake. Earth Sci Rev 42:95-117

McLean RJC, Jamieson HE, Cullimore DR (1997) Formation of nesquehonite and other minerals as a consequence of biofilm dehydration. World J Microb Biot 13(1):25-28

Menon RR, Luo J, Chen X, Zhou H, Liu Z, Zhou G, Zhang N, Jin C (2019) Screening of fungi for potential application of self-healing concrete. Sci Rep 9(1):2075

Minto JM, MacLachlan E, El Mountassir G, Lunn RJ (2016) Rock fracture grouting with microbially induced carbonate precipitation. Water Resour Res 52(11):8827-8844

Minto JM, Lunn RJ, El Mountassir G (2019) Development of a reactive transport model for field-scale simulation of microbially induced carbonate precipitation. Water Resour Res 55(8):7229-7245

Miot J, Remusat L, Duprat E, Gonzalez A, Pont S, Poinsot M (2015) Fe biomineralization mirrors individual metabolic activity in a nitrate-dependent Fe (II)-oxidizer. Front Microbiol 6:879

Mitchell AC, Ferris FG (2005) The co-precipitation of Sr into calcite precipitates induced by bacterial ureolysis in artificial groundwater-temperature and kinetic dependence. Geochim Cosmochim Acta 69:4199-4210

Mitchell AC, Ferris FG (2006) Effect of strontium contaminants on the size and solubility of calcite crystals precipitated by the bacterial hydrolysis of urea. Environ Sci Technol 40:1008-1014

Mitchell JK, Santamarina JC (2005) Biological considerations in geotechnical engineering. $\mathrm{J}$ Geotech Geoenviron 131(10):1222-1233

Mitchell AC, Phillips A, Schultz L, Parks S, Spangler L, Cunningham $\mathrm{AB}$, Gerlach R (2013) Microbial $\mathrm{CaCO}_{3}$ mineral formation and stability in an experimentally simulated high pressure saline aquifer with supercritical $\mathrm{CO}_{2}$. Int $\mathrm{J}$ Greenhouse Gas Control 15:86-96

Mitchell AC, Espinosa-Ortiz EJ, Parks SL, Phillips AJ, Cunningham AB, Gerlach R (2019) Kinetics of calcite precipitation by ureolytic bacteria under aerobic and anaerobic conditions. Biogeosciences 16(10):2147-2161

Mobley H, Island MD, Hausinger RP (1995) Molecular biology of microbial ureases. Microbiol Rev 59:451-480

Mortensen B, Haber M, DeJong J, Caslake L, Nelson D (2011) Effects of environmental factors on microbial induced calcium carbonate precipitation. J Appl Microbiol 111(2):338-349

Mujah D, Shahin MA, Cheng L (2017) State-of-the-art review of biocementation by microbially induced calcite precipitation (MICP) for soil stabilization. Geomicrobiol J 34(6):524-537
Nassar MK, Gurung D, Bastani M, Ginn TR, Shafei B, Gomez MG, Graddy CM, Nelson DC, DeJong JT (2018) Largescale experiments in microbially induced calcite precipitation (MICP): reactive transport model development and prediction. Water Resour Res 54(1):480-500

Nauhaus K, Boetius A, Krüger M, Widdel F (2002) In vitro demonstration of anaerobic oxidation of methane coupled to sulphate reduction in sediment from marine gas hydrate area. Environ Microbiol 4(5):298-305

Nemati M, Voordouw G (2003) Modification of porous media permeability, using calcium carbonate produced enzymatically in situ. Enzyme Microb Technol 33:635-642

Neupauer RM, Meiss JD, Mays DC (2014) Chaotic advection and reaction during engineered injection and extraction in heterogeneous porous media. Water Resour Res 50:1433-1447

Neuville A, Renaud L, Luu TT, Minde MW, Jettestuen E, Vinningland JL, Hiorth A, Dysthe DK (2017) Xurography for microfluidics on a reactive solid. Lab Chip 17:293-303

Nguyen J, Lara-Gutiérrez J, Stocker R (2020) Environmental fluctuations and their effects on microbial communities, populations, and individuals. FEMS Microbiol Rev. https://doi.org/10.1093/femsre/fuaa068

Nguyen J, Fernandez V, Pontrelli S, Sauer U, Ackermann M, Stocker R (2021) A distinct growth physiology enhances bacterial growth under rapid nutrient fluctuations. Nat Commun 12:3662. https://doi.org/10.1038/s41467-02123439-8

Ni B, Ghosh B, Paldy FS, Colin R, Heimerl T, Sourjik V (2017) Evolutionary remodeling of bacterial motility checkpoint control. Cell Rep 18:866-877

Nogues JP, Fitts JP, Celia MA, Peters CA (2013) Permeability evolution due to dissolution and precipitation of carbonates using reactive transport modeling in pore networks. Water Resour Res 49:6006-6021

Okumura T, Takashima C, Kano A (2013) Textures and processes of laminated travertines formed by unicellular cyanobacteria in Myoken hot spring. Southwestern Japan Isl Arc 22:410-426

Okwadha GD, Li J (2010) Optimum conditions for microbial carbonate precipitation. Chemosphere 81(9):1143-1148

Or D, Smets BF, Wraith JM, Dechesne A, Friedman SP (2007) Physical constraints affecting bacterial habitats and activity in unsaturated porous media-a review. Adv Water Resour 30(6-7):1505-1527

Osselin F, Kondratiuk P, Budek A, Cybulski O, Garstecki P, Szymczak P (2016) Microfluidic observation of the onset of reactive-infiltration instability in an analog fracture. Geophys Res Lett 43:6907-6915

Parchert KJ, Spilde MN, Porras-Alfaro A, Nyberg AM, Northup DE (2012) Fungal communities associated with rock varnish in black canyon, New Mexico: casual inhabitants or essential partners? Geomicrobiol J 29:752-766

Pérez-Huerta A, Coronado I, Hegna TA (2018) Understanding biomineralization in the fossil record. Earth Sci Rev 179:95-122

Petroff AP, Sim MS, Maslov A, Krupenin M, Rothman DH, Bosak T (2010) Biophysical basis for the geometry of conical stromatolites. Proc Natl Acad Sci 107(22):9956-9961 
Pham TD, Shrestha RA, Virkutyte J, Sillanpää M (2009) Recent studies in environmental applications of ultrasound. Can J Civ Eng 36(11):1849-1858

Phillips AJ, Lauchnor E, Eldring J, Esposito R, Mitchell AC, Gerlach R, Cunningham AB, Spangler LH (2012) Potential $\mathrm{CO}_{2}$ leakage reduction through biofilm-induced calcium carbonate precipitation. Environ Sci Technol 47(1):142-149

Phillips AJ, Gerlach R, Lauchnor E, Mitchell AC, Cunningham AB, Spangler L (2013) Engineered applications of ureolytic biomineralization: a review. Biofouling 29(6):715-733

Phillips AJ, Eldring JJ, Hiebert R, Lauchnor E, Mitchell AC, Cunningham A, Spangler L, Gerlach R (2015) Design of a meso-scale high pressure vessel for the laboratory examination of biogeochemical subsurface processes. J Petrol Sci Eng 126:55-62

Phillips AJ, Cunningham AB, Gerlach R, Hiebert R, Hwang C, Lomans BP, Westrich J, Mantilla C, Kirksey J, Esposito R, Spangler L (2016) Fracture sealing with microbially-induced calcium carbonate precipitation: a field study. Environ Sci Technol 50(7):4111-4117

Pitt WG, Ross SA (2003) Ultrasound increases the rate of bacterial cell growth. Biotechnol Prog 19(3):1038-1044

Piyasena P, Mohareb E, McKellar RC (2003) Inactivation of microbes using ultrasound: a review. Int J Food Microbiol 87(3):207-216

Porter ML, Jiménez-Martínez J, Martinez R, McCulloch Q, Carey JW, Viswanathan HS (2015) Geo-material microfluidics at reservoir conditions for subsurface energy resource applications. Lab Chip 15:4044-4053

Prasianakis NP, Curti E, Kosakowski G, Poonoosamy J, Churakov SV (2017) Deciphering pore-level precipitation mechanisms. Sci Rep 7(1):13765

Prentice IC, Farquhar GD, Fasham MJR, Goulden ML, Heimann M, Jaramillo VJ, Kheshgi HS, LeQuéré C, Scholes RJ, Wallace DW (2001) The carbon cycle and atmospheric carbon dioxide. Cambridge University Press

Qin CZ, Hassanizadeh SM, Ebigbo A (2016) Pore-scale network modeling of microbially induced calcium carbonate precipitation: Insight into scale dependence of biogeochemical reaction rates. Water Resour Res 52:8794-8810. https://doi.org/10.1002/2016WR019128

Radu DA, Isopescu R, Panturu E, Woinaroschy A (2020) Optimization of uranium soil decontamination in alkaline washing using mechanical stirring and ultrasound field. Environ Sci Pollut Res 27(6):5941-5950

Rebata-Landa V (2007) Microbial activity in sediments: effects on soil behavior Ph.D. Dissertation, Georgia Institute of Technology, Atlanta, GA

Riding R, Awramik SM (2000) Microbial sediments. Springer, Berlin/Heidelberg/New York

Robinson DA, Binley A, Crook N, Day-Lewis FD, Ferré TPA, Grauch VJS, Knight R, Knoll M, Lakshmi V, Miller R, Nyquist J (2008) Advancing process-based watershed hydrological research using near-surface geophysics: a vision for, and review of, electrical and magnetic geophysical methods. Hydrol Process 22(18):3604-3635

Roden EE, Scheibe TD (2005) Conceptual and numerical model of uranium (VI) reductive immobilization in fractured subsurface sediments. Chemosphere 59(5):617-628
Rodriguez-Navarro C, Rodriguez-Gallego M, Ben Chekroun K, Gonzalez-Muñoz MT (2003) Conservation of ornamental stone by Myxococcus xanthus-induced carbonate biomineralization. Appl Environ Microbiol 69:2182-2193

Rodriguez-Navarro C, Jroundi F, Schiro M, Ruiz-Agudo E, González-Muñoz MT (2012) Influence of substrate mineralogy on bacterial mineralization of calcium carbonate: implications for stone conservation. Appl Environ Microbiol 78(11):4017-4029

Rolle M, Eberhardt C, Chiogna G, Cirpka OA, Grathwohl P (2009) Enhancement of dilution and transverse reactive mixing in porous media: experiments and model-based interpretation. J Contam Hydrol 110(3-4):130-142

Haggerty R, Martí E, Argerich A, von Schiller D, Grimm NB (2009) Resazurin as a "smart" tracer for quantifying metabolically active transient storage in stream ecosystems. J Geophy Res 114(G3). https://doi.org/10.1029/ 2008JG000942

Rusconi R, Guasto JS, Stocker R (2014) Bacterial transport is suppressed by fluid shear. Nat Phys 10:212-217

Rusu C, Cheng X, Li M (2011) Biological clogging in Tangshan sand columns under salt water intrusion by Sporosarcina pasteurii. Adv Mater Res 250:2040-2046

Salifu E, MacLachlan E, Iyer KR, Knapp CW, Tarantino A (2016) Application of microbially induced calcite precipitation in erosion mitigation and stabilisation of sandy soil foreshore slopes: a preliminary investigation. Eng Geol 201:96-105

Sánchez-Román M, Romanek CS, Fernández-Remolar DC, Sánchez-Navas A, McKenzie JA, Pibernat RA, Vasconcelos C (2011) Aerobic biomineralization of Mg-rich carbonates: Implications for natural environments. Chem Geol 281(3-4):143-150

Sanjuan B, Girard JP (1996) Review of kinetic data on carbonate mineral precipitation. BRGM Rep R39062(1996):91p

Sanz R, Battu S, Puignou L, Galceran MT, Cardot PJ (2003) Sonication effect on cellular material in sedimentation and gravitational field flow fractionation. J Chromatogr A 1002(1-2):145-154

Sarikaya M (1999) Biomimetics: materials fabrication through biology. Proc Natl Acad Sci 96:14183-14185

Sarkar M, Alam N, Chaudhuri B, Chattopadhyay B, Mandal S (2015) Development of an improved E coli bacterial strain for green and sustainable concrete technology. RSC Adv 5(41):32175-32182

Satoh H, Nishimura Y, Tsukamoto K, Ueda A, Kato K, Ueta S (2007) In-situ measurement of dissolution of anorthite in $\mathrm{Na}-\mathrm{Cl}-\mathrm{OH}$ solutions at $22^{\circ} \mathrm{C}$ using phase-shift interferometry. Am Mineral 92:503-509

Scheidweiler D, Peter H, Pramateftaki P, de Anna P, Battin TJ (2019) Unraveling the biophysical underpinnings to the success of multispecies biofilms in porous environments. ISME J 13(7):1700-1710

Scheidweiler D, Miele F, Peter H, Battin TJ, de Anna P (2020) Trait-specific dispersal of bacteria in heterogeneous porous environments: from pore to porous medium scale. J R Soc Interface 17(164):20200046

Schlegel HG, Zaborosch C (1993) General microbiology. Cambridge University Press

Scholl MA, Mills AL, Herman JS, Hornberger GM (1990) The influence of mineralogy and solution chemistry on the 
attachment of bacteria to representative aquifer materials. J Contam Hydrol 6(4):321-336

Schultz L, Pitts B, Mitchell AC, Cunningham AB, Gerlach R (2011) Imaging biologically induced mineralization in fully hydrated flow systems. Microscopy Today 19(5):12-15

Secchi E, Vitale A, Miño GL, Kantsler V, Eberl L, Rusconi R, Stocker R (2020) The effect of flow on swimming bacteria controls the initial colonization of curved surfaces. Nat Commun 11:2851. https://doi.org/10.1038/s41467-02016620-y

Seifan M, Samani AK, Berenjian A (2016) Bioconcrete: next generation of self-healing concrete. Appl Microbiol Biotechnol 100(6):2591-2602

Seiffert F, Bandow N, Bouchez J, Von Blanckenburg F, Gorbushina AA (2014) Microbial colonization of bare rocks: laboratory biofilm enhances mineral weathering. Procedia Earth Planet Sci 10:123-129

Singh R, Yoon H, Sanford RA, Katz L, Fouke BW, Werth CJ (2015) Metabolism-induced $\mathrm{CaCO}_{3}$ biomineralization during reactive transport in a micromodel: implications for porosity alteration. Environ Sci Technol 49(20):12094-12104

Singh R, Sivaguru M, Fried GA, Fouke BW, Sanford RA, Carrera M, Werth CJ (2017) Real rock-microfluidic flow cell: a test bed for real-time in situ analysis of flow, transport, and reaction in subsurface reactive transport environment. J Cont Hydrol 204:28-39

Skinner HCW, Jahren AH (2005) Biomineralization. In: Schlesinger WH (ed) Biogeochemistry treatise on geochemistry 8. Elsevier, Amsterdam, The Netherlands, pp 117-184

Son K, Brumley DR, Stocker R (2015) Live from under the lens: exploring microbial motility with dynamic imaging and microfluidics. Nat Rev Microbiol 13:761-775

Song W, de Hass TW, Fadaei H, Sinton D (2014) Chip-off-theold-rock: the study of reservoir-relevant geological processes with real-rock micromodels. Lab Chip $14: 4382-4390$

Southam G (2000) Bacterial surface-mediated mineral formation. In: Lovley DR (ed) Environmental microbe-metal interactions. ASM Press, Washington, D.C., pp 257-276

Spycher NF, Issarangkun M, Stewart BD, Şengör SS, Belding E, Ginn TR, Peyton BM, Sani RK (2011) Biogenic uraninite precipitation and its reoxidation by iron (III)(hydr) oxides: a reaction modeling approach. Geochim Cosmochim Acta 75(16):4426-4440

Sutton M, Reis S and Baker S (2009) Atmospheric ammonia: detecting emission changes and environmental impacts In results of an expert workshop under the convention on long-range transboundary air pollution, Springer

Tazaki K, Rafiqul IA, Nagai K, Kurihara T (2003) FeAs biomineralization on encrusted bacteria in hot springs: an ecological role of symbiotic bacteria. Can J Earth Sci 40(11):1725-1738

Tecon R, Or D (2017) Biophysical processes supporting the diversity of microbial life in soil. FEMS Microbiol Rev 41(5):599-623

Terzis D, Laloui L (2018) 3-D micro-architecture and mechanical response of soil cemented via microbial-induced calcite precipitation. Sci Rep 8(1):1416
Terzis D, Laloui L (2019) A decade of progress and turning points in the understanding of bio-improved soils: a review. Geomech Energy Environ 19:100116

Thullner M, Mauclaire L, Schroth MH, Kinzelbach W, Zeyer J (2002) Interaction between water flow and spatial distribution of microbial growth in a two-dimensional flow field in saturated porous media. $\mathrm{J}$ Contam Hydrol 58(3-4):169-189

Tobler DJ, Cuthbert MO, Greswell RB, Riley MS, Renshaw JC, Handley-Sidhu S, Phoenix VR (2011) Comparison of rates of ureolysis between Sporosarcina pasteurii and an indigenous groundwater community under conditions required to precipitate large volumes of calcite. Geochim Cosmochim Acta 75(11):3290-3301

Tobler DJ, Maclachlan E, Phoenix VR (2012) Microbially mediated plugging of porous media and the impact of differing injection strategies. Ecol Eng 42:270-278

Trefry MG, Lester DR, Metcalfe G, Ord A, Regenauer-Lieb K (2012) Toward enhanced subsurface intervention methods using chaotic advection. J Contam Hydrol 127(1-4):15-29

Valdes-Abellan J, Jiménez-Martínez J, Candela L, Jacques D, Kohfahl C, Tamoh K (2017) Reactive transport modelling to infer changes in soil hydraulic properties induced by non-conventional water irrigation. J Hydrol 549:114-124

van Cappellen P (2003) Biomineralization and global biogeochemical cycles. Rev Mineral Geochem 54(1):357-381

van Veen JA, van Overbeek LS, van Elsas JD (1997) Fate and activity of microorganisms introduced into soil. Microbiol Mol Biol Rev 61:121-135

van Wijngaarden WK, Vermolen FJ, van Meurs GA, Vuik C (2011) Modelling biogrout: a new ground improvement method based on microbial-induced carbonate precipitation. Transport Porous Med 87:397-420

van Wijngaarden WK, Vermolen FJ, van Meurs GAM, Vuik C (2013) A mathematical model for biogrout: bacterial placement and soil reinforcement. Computat Geosci 17:463-478

van Wijngaarden WK, van Paassen LA, Vermolen FJ, van Meurs GAM, Vuik C (2016) A reactive transport model for biogrout compared to experimental data. Transport Porous Med 111:627-648

Vanderborght J, Vereecken H (2007) Review of dispersivities for transport modeling in soils. Vadose Zone J 6(1):29-52

Wang X, Nackenhorst U (2020) A coupled bio-chemo-hydraulic model to predict porosity and permeability reduction during microbially induced calcite precipitation. Adv Water Res 140. https://doi.org/10.1016/j.advwatres.2020.103563

Wang LL, Wang LF, Ren XM, Ye XD, Li WW, Yuan SJ, Sun M, Sheng GP, Yu HQ, Wang XK (2012ba) pH dependence of structure and surface properties of microbial EPS. Environ Sci Technol 46(2):737-744

Wang J, Van Tittelboom K, De Belie N, Verstraete W (2012b) Use of silica gel or polyurethane immobilized bacteria for self-healing concrete. Constr Build Mater 26(1):532-540

Wang H, Teng F, Yang X, Guo X, Tu J, Zhang C, Zhang D (2017) Preventing microbial biofilms on catheter tubes using ultrasonic guided waves. Sci Rep. https://doi.org/10. 1038/s41598-017-00705-8

Wang Y, Soga K, DeJong JT, Kabla AJ (2019) A microfluidic chip and its use in characterising the particle-scale 
behaviour of microbial-induced calcium carbonate precipitation (MICP). Géotechnique 69(12):1086-1094

Weber WJ Jr, McGinley PM, Katz LE (1992) A distributed reactivity model for sorption by soils and sediments 1 Conceptual basis and equilibrium assessments. Environ Sci Technol 26(10):1955-1962

Weiner S, Dove PM (2003) An overview of biomineralization processes and the problem of the vital effect. In: Dove PM, de Yoreo JJ, Weiner S (eds) Biomineralization. Mineralogical Society of America, Chantilly VA USA, pp 1-29

Whiffin VS, van Paassen LA, Harkes MP (2007) Microbial carbonate precipitation as a soil improvement technique. Geomicrobiol J 24(5):417-423

Williams KH, Kemna A, Wilkins MJ, Druhan J, Arntzen E, N'Guessan AL, Long PE, Hubbard SS, Banfield JF (2009) Geophysical monitoring of coupled microbial and geochemical processes during stimulated subsurface bioremediation. Environ Sci Technol 43(17):6717-6723

Wu Y, Hubbard S, Williams KH, Ajo-Franklin J (2010) On the complex conductivity signatures of calcite precipitation. J Geophys Res 115:G00G04. https://doi.org/10.1029/ 2009JG001129

Wu J, Wang HF, Wang XB, Yang HY, Jiang RY, Zeng RJ (2017) Design and characterization of a microbial selfhealing gel for enhanced oil recovery. RSC Adv 7(5):2578-2586

Xiao P, Liu H, Xiao Y, Stuedlein AW, Evans TM (2018) Liquefaction resistance of bio-cemented calcareous sand. Soil Dyn Earthq Eng 107:9-19

Yin H, Ji B, Dobson PS, Mosbahi K, Glidle A, Gadegaard N, Freer A, Cooper JM, Cusack M (2009) Screening of biomineralization using microfluidics. Anal Chem 81(1):473-478

Yong YC, Wu XY, Sun JZ, Cao YX, Song H (2015) Engineering quorum sensing signaling of Pseudomonas for enhanced wastewater treatment and electricity harvest: a review. Chemosphere 140:18-25

Zambare NM, Lauchnor EG, Gerlach R (2019) Controlling the distribution of microbially precipitated calcium carbonate in radial flow environments. Environ Sci Technol 53(10):5916-5925
Zango MU, Kassim KA, Mohammed AS (2018) Bio-desaturation and bio-sealing techniques for mitigation of soil liquefaction: a review. In MATEC Web of Conferences 250:01018

Zhang S (2020) The relationship between organoclastic sulfate reduction and carbonate precipitation/dissolution in marine sediments. Mar Geol 428:106284

Zhang Z, Furman A (2021) Soil redox dynamics under dynamic hydrologic regimes-A review. Sci Tot Environ 763:143026

Zhang T, Klapper I (2014) Critical occlusion via biofilm induced calcite precipitation in porous media. New J Phys. https://doi.org/10.1088/1367-2630/16/5/055009

Zhang J, Burrows S, Gleason C, Matthews MA, Drews MJ, Laberge M, An HA (2006) Sterilizing Bacillus pumilus spores using supercritical carbon dioxide. J Microbiol Methods 66:479-485

Zhang C, Slater L, Redden G, Fujita Y, Johnson T, Fox D (2012) Spectral induced polarization signatures of hydroxide adsorption and mineral precipitation in porous media. Environ Sci Technol 46(8):4357-4364

Zhang J, Liu Y, Feng T, Zhou M, Zhao L, Zhou A, Li Z (2017) Immobilizing bacteria in expanded perlite for the crack self-healing in concrete. Constr Build Mater 148:610-617

Zhao Q, Li L, Li C, Li M, Amini F, Zhang H (2014) Factors affecting improvement of engineering properties of MICPtreated soil catalyzed by bacteria and urease. J Mater Civil Eng 26(12):04014094

Zhu T, Dittrich M (2016) Carbonate precipitation through microbial activities in natural environment, and their potential in biotechnology: a review. Front Bioeng Biotechnol 4:4. https://doi.org/10.3389/fbioe.2016.00004

Zhu H, Carlson HK, Coates JD (2013) Applicability of anaerobic nitrate-dependent $\mathrm{Fe}$ (II) oxidation to microbial enhanced oil recovery (MEOR). Environ Sci Technol 47(15):8970-8977

Publisher's Note Springer Nature remains neutral with regard to jurisdictional claims in published maps and institutional affiliations. 